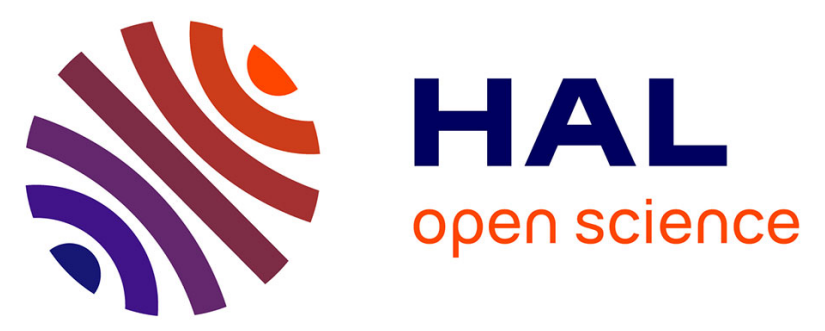

\title{
Environmental changes, climate and anthropogenic impact in southern-eastern Tunisia during the last $8 \mathrm{kyr}$
}

S. Jaouadi, Vincent Lebreton, Viviane Bout-Roumazeilles, G. Siani, R. Lakhdar, Ridha Boussoffara, Laurent Dezileau, Nejib Kallel, Beya

Mannai-Tayech, N. Combourieu-Nebout

\section{To cite this version:}

S. Jaouadi, Vincent Lebreton, Viviane Bout-Roumazeilles, G. Siani, R. Lakhdar, et al.. Environmental changes, climate and anthropogenic impact in southern-eastern Tunisia during the last $8 \mathrm{kyr}$. Climate of the Past, 2016, 12 (6), pp.1339-1359. 10.5194/cp-12-1339-2016 . hal-01319967

\section{HAL Id: hal-01319967 \\ https://hal.science/hal-01319967}

Submitted on 29 May 2017

HAL is a multi-disciplinary open access archive for the deposit and dissemination of scientific research documents, whether they are published or not. The documents may come from teaching and research institutions in France or abroad, or from public or private research centers.
L'archive ouverte pluridisciplinaire HAL, est destinée au dépôt et à la diffusion de documents scientifiques de niveau recherche, publiés ou non, émanant des établissements d'enseignement et de recherche français ou étrangers, des laboratoires publics ou privés. 


\title{
Environmental changes, climate and anthropogenic impact in south-east Tunisia during the last $8 \mathrm{kyr}$
}

\author{
Sahbi Jaouadi ${ }^{1}$, Vincent Lebreton ${ }^{1}$, Viviane Bout-Roumazeilles ${ }^{2}$, Giuseppe Siani ${ }^{3}$, Rached Lakhdar ${ }^{4}$, \\ Ridha Boussoffara $^{5}$, Laurent Dezileau ${ }^{6}$, Nejib Kallel ${ }^{7}$, Beya Mannai-Tayech ${ }^{8}$, and Nathalie Combourieu-Nebout ${ }^{1}$ \\ ${ }^{1}$ UMR 7194 CNRS, Histoire naturelle de l'Homme Préhistorique, Département de Préhistoire, Muséum national d’Histoire \\ naturelle, Paris, France \\ ${ }^{2}$ Laboratoire d'Océanologie et de Géosciences LOG, UMR8187, CNRS-Université Lille-Université Côte d'Opale, \\ 59655 Villeneuve d'Ascq, France \\ ${ }^{3}$ Laboratoire des Interactions et Dynamique des Environnements de Surface (IDES), UMR8148, CNRS-Université de \\ Paris-Sud, Bat 504, 91405 Orsay CEDEX, France \\ ${ }^{4}$ Faculté des Sciences de Bizerte, Université de Carthage, 7021 Zarzouna, Bizerte, Tunisia \\ ${ }^{5}$ Institut National du Patrimoine, 4 Place du Château, 1008 Tunis, Tunisia \\ ${ }^{6}$ UMR 5243 CNRS, Géosciences Montpellier, Université de Montpellier, Montpellier, France \\ ${ }^{7}$ Université de Sfax, Faculté des Sciences, Laboratoire GEOGLOB, BP 802, 3038 Sfax, Tunisia \\ ${ }^{8}$ Université de Tunis El Manar, Faculté des Sciences de Tunis, 2092 Tunis, Tunisia
}

Correspondence to: Sahbi Jaouadi (jaouadisahbi@yahoo.com)

Received: 25 February 2016 - Published in Clim. Past Discuss.: 29 February 2016

Revised: 23 May 2016 - Accepted: 24 May 2016 - Published: 15 June 2016

\begin{abstract}
Pollen and clay mineralogical analyses of a Holocene sequence from Sebkha Boujmel (southern Tunisia) trace the climatic and environmental dynamics in the lower arid bioclimatic zone over the last 8000 years. During the mid- to late Holocene transition, between ca. 8 and $3 \mathrm{ka} \mathrm{BP}$, a succession of five wet-dry oscillations is recorded. An intense arid event occurs between ca. 5.7 and $4.6 \mathrm{ka} \mathrm{BP}$. This episode marks the onset of a long-term aridification trend with a progressive retreat of Mediterranean woody xerophytic vegetation and of grass steppes. It ends with the establishment of pre-desert ecosystems around $3 \mathrm{kaBP}$. The millennial-scale climate change recorded in the data from Sebkha Boujmel is consistent with records from the south and east Mediterranean, as well as with climatic records from the desert region for the end of the African Humid Period (AHP). Eight centennial climatic events are recorded at Sebkha Boujmel and these are contemporary with those recorded in the Mediterranean and in the Sahara. They indicate a clear coupling between the southern Mediterranean and the Sahara before $3 \mathrm{kaBP}$. The event at $4.2 \mathrm{ka} \mathrm{BP}$ is not evidenced and the link between events recorded in Sebkha Boujmel and the North Atlantic cooling events is clearer from ca. $3 \mathrm{ka} \mathrm{BP}$ on-
\end{abstract}

wards. These variations indicate the importance of climatic determinism in the structuring of landscapes, with the establishment of the arid climatic conditions of the late Holocene. It is only from ca. $3 \mathrm{ka} \mathrm{BP}$ onwards that the dynamic of plant associations is modified by both human activity and climatic variability. The climatic episodes identified during the historic period indicate strong regionalisation related to the differential impact of the North Atlantic Oscillation (NAO) and the Mediterranean Oscillation (MO) on the Mediterranean Basin. The local human impact on regional ecosystems is recorded in the form of episodes of intensification of pastoral and/or agricultural activities. The development of olive production and of several taxa associated with agriculture attest to increasing sedentism among human populations during classical antiquity. The significant increase in Artemisia (wormwood) between ca. 1.1 and $0.8 \mathrm{ka} \mathrm{BP}$ (850-1150 AD) is linked to intensive pastoral activity, associated with heightened interannual and/or seasonal climatic instability. A complete reshaping of the landscape is recorded during the 20th century. The remarkable expansion of the olive tree, and the deterioration of regional ecosystems with the spread of desert 
species, is linked to recent local socio-economic changes in Tunisia.

\section{Introduction}

Subjected to climatic influences from both polar high latitudes and subtropical low latitudes, the Mediterranean Basin is considered to be one of the regions most exposed to climatic change (IPCC, 2014). Its ecosystems are particularly vulnerable to hydrological changes as well as to strong demographic pressure, particularly in coastal areas (Lionello et al., 2006; IPCC, 2014). In this context, the desert margins and arid ecosystems of northern Africa constitute climatic and biogeographical transition zones that are among the most sensitive to variations in climatic parameters and human activities (Smykatz-Kloss and Felix-Henningsen, 2004). Among these regions, south-eastern Tunisia is currently crippled by arid conditions and increasing human pressure, leading to a marked degradation of its natural environment and increased desertification (Floret and Pontanier, 1982; Genin et al., 2006). Moreover, prospective studies foresee a prolonging of drought periods and intensified desertification due to the effects of global warming (e.g. Gao and Giorgi, 2008; Giorgi and Lionello, 2008; Nasr et al., 2008; Giannakopoulos et al., 2009).

In the northern Mediterranean, numerous palaeoecological records reveal the climate dynamics for the middle to late Holocene (e.g. Roberts et al., 2011; Sadori et al., 2011; Magny et al., 2013; Azuara et al., 2015). For the Sahara, the scale of Holocene climate change, with the establishment of a hyper-arid desert, has been estimated using multi-proxy analyses (e.g. deMenocal et al., 2000; Swezey, 2001; Gasse and Roberts, 2004; Hoelzmann et al., 2004; Kröpelin et al., 2008; Lézine et al., 2011; McGee et al., 2013; Tierney and deMenocal, 2013; Cremaschi et al., 2014). However, palaeoecological and palaeoclimatic records from the southern Mediterranean are still needed in order to complete the pattern of environmental and climatic changes along a latitudinal transect in the Mediterranean region. In fact, during the early and middle Holocene, the climatic and hydrological contrast between the northern and southern parts of the Mediterranean Basin is already apparent (Magny et al., 2012, 2013; Peyron et al., 2013). Regional-scale climate modelling simulations spanning the Holocene also reveal a climatic contrast between the east and west shores of the Mediterranean, along a line passing between Italy and Tunisia (Brayshaw et al., 2011). Today, there is still a dearth of available data for the southern shore of the Mediterranean, and in particular for the arid regions of northern Africa, thus providing only a fragmentary view of Holocene climate changes. Indeed, the scarcity of suitable deposits for pollen analyses in the arid regions has limited the acquisition of palaeoecological data (Horowitz, 1992; Carrión, 2002b). The lack of data for semi-arid and arid bioclimatic areas has been highlighted in
Holocene climatic syntheses in the Mediterranean (Tzedakis, 2007; Roberts et al., 2011), leading to geographical gaps in the outputs from climate modelling simulations (Brayshaw et al., 2011; Peyron et al., 2011).

In the pre-desert steppes of the Maghreb, data regarding lake-level variations (Gasse, 2000; Callot and Fontugne, 2008), geomorphological features (e.g. Ballais, 1991; Ballais and Ouezdou, 1991; Boujelben, 2015), sand dune dynamics (Swezey et al., 1999; Swezey, 2001) and pollen sequences (Brun, 1983, 1992; Damblon and Vanden Berghen, 1993; Salzmann and Schulz, 1995) are characterised by low temporal resolutions and are geographically and chronologically dispersed. These data indicate a more humid climate during the early and middle Holocene followed by an increase in aridity over the course of the late Holocene.

Analysis of past environmental dynamics in pre-Saharan Tunisia is crucial and should allow the characterisation of (1) the biogeographical history of the present landscape, (2) the resilience of vegetation in response to aridity and human disturbance, and (3) the processes of the degradation and desertification of desert margins (Schaaf, 2008). Recent work undertaken on the continental Sebkha Mhabeul in southern Tunisia (Schulz et al., 2002; Marquer et al., 2008) and the Halk el Menjel sebkha lagoon in central Tunisia (Lebreton and Jaouadi, 2013; Lebreton et al., 2015) has already revealed the huge potential of sebkhas for pollen analysis. Sebkha Boujmel, on the southern coast of Tunisia, has yielded the first continuous geochemical and pollen record for the last 8000 years. The sequence reveals the vegetation history in the transition zone between the Mediterranean and the Sahara. In this study, vegetation dynamics and climatic changes are integrated in a transect of the central Mediterranean in order to identify their rhythmicity and to correlate them with regional and global climate changes. The human impact is considered within the cultural framework of Tunisian archaeology and history.

\section{Geographical settings, climate and current vegetation}

Today, south-eastern Tunisia is dominated by an arid Mediterranean climate, having a long dry season with occasional and highly irregular precipitation. Two hydro-climatic gradients are evident from north to south and from east to west, under the combined influence of proximity to the Mediterranean coast and upland topography, which captures humid air masses (Berndtsson, 1989). Three climatic and phytogeographical territories have been identified for southeastern Tunisia: the Matmata mountain range, the desert and the Jeffara pre-desert coastal plain (Le Houérou, 1959, 1995; Floret and Pontanier, 1982; Genin et al., 2006) (Fig. 1b).

In the Matmata Mountains zone, to the west, increased humidity on relief up to $700 \mathrm{~m}$ produces an altitudinal distribution of vegetation (botanical nomenclature follows Le 


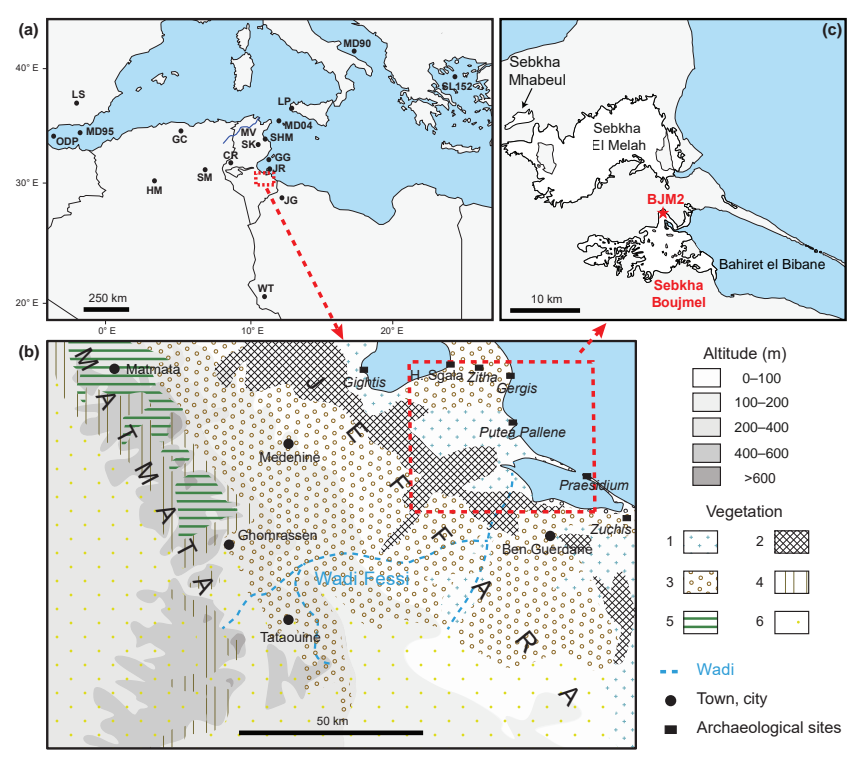

Figure 1. Geographical settings. (a) Large map of the Mediterranean Basin showing the location of the study area (outlined in red in map b and shown in detail in c) and of selected Mediterranean records referred to in the text. CR: Chott Rharsa; GC: Gueldaman Cave; GG: Golfe de Gabès; HM: Hassi el Mejnah; JG: Jbel Gharbi; JR: Île de Jerba; LP: Lake Preola; LS: Lake Siles; MD04: core MD 04-2797; MD90: core MD 90-917; MD95: core MD 952043; MV: Medjerda Valley; ODP: ODP site 976; SHM: Sebkha Halk el Menjel; SK: Sebkha Kalbiyya; SM: Sebkha Mellala; WT: Wadi Teshuinat. (b) Inset map that shows main regional setting for Sebkha Boujmel including topography, vegetation (after Gammar, 2008), hydrographic network, archaeological sites (after Drine, 1993) and current cities. Vegetation 1: halophilous vegetation. 2: gypsophilous steppe with Lygeum and Zygophyllum. 3: cultivated fields (Olea) and steppe with Rhanterium, Haloxylon scoparium and Artemisia. 4: steppe with Haloxylon scoparium and Haloxylon schimittianum. 5: steppe with Stipa tenacessima and matorral with Juniperus phoenicea. 6: desert vegetation with Helianthemum sp., Calligonum, Gymnocarpos decander and Traganum nudatum. (c) Detailed map displays the location of Sebkha Boujmel, the studied core (BJM2) and other nearby sebkhas mentioned in the text.

Floc'h et al., 2010) (Fig. 1b). The northern summits of the Matmata Mountains, which have a more humid climate (with average precipitation values of between 200 and $300 \mathrm{~mm}$ per annum), are part of the upper arid bioclimatic zone. On these summits, a low shrubland of Juniperus phoenicea and Rosmarinus officinalis develops locally. This vegetation gradually gives way to grassy and semi-desert steppe to the east and south due to increased aridity as one descends into the foothills (Fig. 1b).

A gradual transition towards the desert area is observed as soon as humidity, due to proximity to the Mediterranean and the uplands, recedes. A desert bioclimate, with annual precipitation below $100 \mathrm{~mm}$, borders on the Matmata mountainous zone and the Jeffara coastal plain with the sand dunes of the Great Eastern Erg to the west and the Sahara to the south (Fig. 1b). Vegetation is sparse and adapted to the arid conditions mainly with psammophyte shrubs such as Calligonum sp., Cornulaca monacantha, Ephedra alata subsp. alenda, Moltkiopsis ciliata, Retama raetam and Traganum nudatum.

Further east, the Jeffara coastal plain, which forms an extensive pre-desert area delimited at the west by the Matmata Mountains, slopes gradually down to the coast (Fig. 1b). The coastal area features a large number of lagoons and coastal sebkhas (Fig. 1c). The Jeffara Plain forms part of the Mediterranean lower arid bioclimatic zone, with mild winters and average annual precipitation of between 100 and $200 \mathrm{~mm}$. It is occupied by semi-desert steppe, featuring Rhanterium suaveolens, Artemisia sp., Haloxylon scoparium, Gymnocarpos decander and degraded grassland steppe with Stipa tenacissima on the foothills and plains with a calcareous crust. A halophytic crassulescent steppe, characterised by Amaranthaceae (Halocnemum, Salicornia, Salsola and Suaeda), develops in the saline soils around the sebkhas. On the Jeffara Plain, the anthropogenic impact is significant and includes ancestral pastoralism as well as recent conversion to agriculture. The Jeffara was originally used as rangeland for nomadic tribes and their flocks. The recent anthropogenic impact takes the form of vast olive groves (Fig. 1b). In this area, the olive is outside its natural bioclimatic zone and its cultivation is made possible through dry-farming and traditional systems for controlling surface run-off in the mountains and foothills (Nasri et al., 2004).

Sebkha Boujmel $\left(33^{\circ} 16^{\prime} \mathrm{N}, 11^{\circ} 05^{\prime} \mathrm{E}, 2 \mathrm{~m}\right.$ a.s.l.) is situated on the coast of the Jeffara Plain and forms part of the paralic complex of Bahiret el Bibane (Fig. 1c). This supratidal sebkha is irregularly flooded by rainwater and high tides via Bahiret el Bibane. Sebkha Boujmel and Bahiret el Bibane correspond to valleys which were incised by the Wadi Fessi during the upper Pleistocene (Medhioub and Perthuisot, 1981). Sebkha Boujmel corresponds to the present-day and Holocene delta of the Wadi Fessi, which rises inland at Tataouine and then drains the mountainous region and the coastal plain (Keer, 1976; Medhioub and Perthuisot, 1981) (Fig. 1b). The Holocene sedimentary filling of Sebkha Boujmel is a typical lagoonal sequence with biodetrital deposits at the base, followed by bioclastic and oolithic carbonate sands and, finally, by detrital facies which are principally of aeolian origin (Fig. 2) (Lakhdar et al., 2006).

\section{Material and methods}

\subsection{Core material and samples}

The BJM2 core $\left(33^{\circ} 18^{\prime} 30.96^{\prime \prime} \mathrm{N}, 11^{\circ} 5^{\prime} 0.68^{\prime \prime} \mathrm{E}, 160 \mathrm{~cm}\right.$ depth) was extracted from the north-west of the sebkha in order to carry out pollen and mineralogical analysis (Fig. 1c). The observed effect of core shortening (12.5\%), which commonly occurs in shallow unconsolidated coastal sediments, has been removed using field measurements following the 


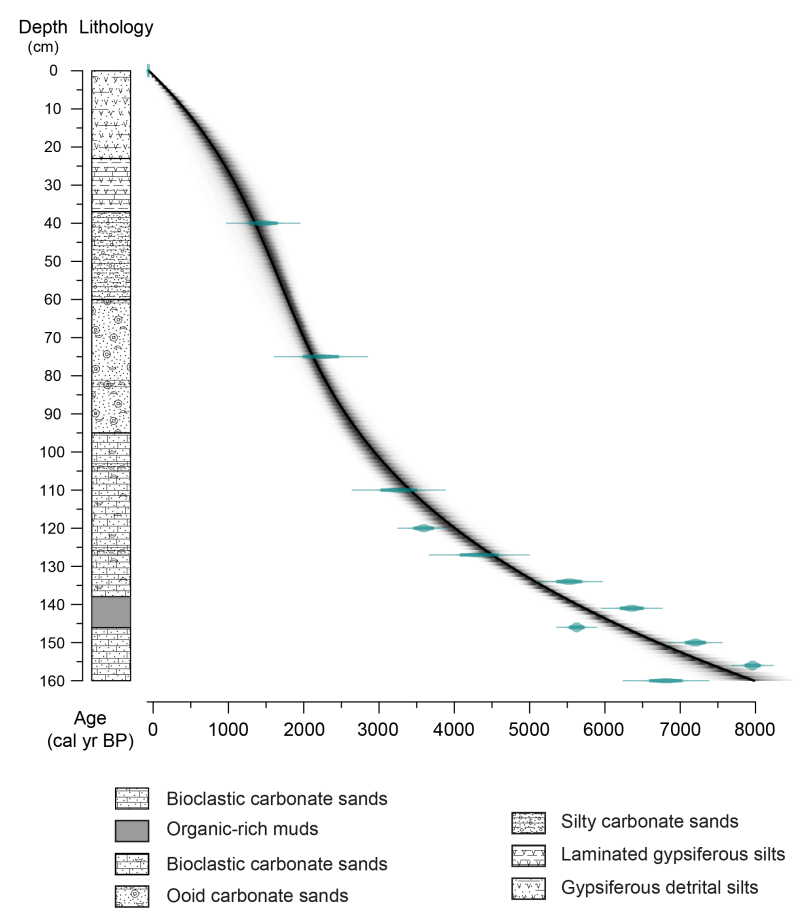

Figure 2. Lithology and age-depth model for BJM2 core. The age model was obtained by third-degree polynomial regression with $10 \mathrm{k}$ model iteration using the package Clam 2.2 (Blaauw, 2010). Grey scales show the distribution of all age models at 500 equally spaced core depths.

method described in Morton and White (1997). In total, 71 samples were selected for palynological and clay mineralogical analyses.

\subsection{Chronology}

The chronology of the BJM2 core is based on 11 accelerator mass spectrometry (AMS) ${ }^{14} \mathrm{C}$ dates determined on the organic fraction of the sediment (Table 1). Study of the organic matter shows that it is of mixed origin, composed of marine planktonic and algal material and continental woody material (Lakhdar, 2009). Input of marine origin is also confirmed by the extensive presence along the core of shallow-dwelling benthic foraminifera of the genus Ammonia as well as Ostracoda and molluscs. The ${ }^{14} \mathrm{C}$ dates were corrected for the reservoir effect, calculated at 400 years for the Mediterranean (Siani et al., 2001) and then calibrated using IntCal13 within the Calib 7.1 programme (Reimer et al., 2013) (Table 1). The date at the top of the sequence, considered to be predominantly under continental influence, was not corrected for the reservoir effect.

The age-depth model (Fig. 2) was elaborated using the Clam software package (Blaauw, 2010; Blaauw and Heegaard, 2012). Models with age reversals were rejected and best goodness of fit was obtained using third-degree polyno- mial regression. The absence of sedimentary hiatus (Lakhdar, 2009), the number of AMS ${ }^{14} \mathrm{C}$ dates and the coherence of the age-depth model limit the influence of erroneous dates or dates impacted upon by a hard-water effect.

The BJM2 core records 8000 years of infill history of Sebkha Boujmel. The sampling resolution varies as a function of the sedimentation rate. It is around $210 \mathrm{yr} \mathrm{sample}^{-1}$ for the period between 8 and $3 \mathrm{kaBP}$, with an average of $60 \mathrm{yr}$ sample ${ }^{-1}$ for the rest of the sequence.

\subsection{Pollen analysis}

The pollen extraction follows the standard protocol (Traverse, 2007): $5 \mathrm{~g}$ of sediment are processed by successive chemical treatments $(\mathrm{HCl} 18 \%, \mathrm{HF} 70 \%$ and $\mathrm{HCl} 10 \%)$, followed by ultrasonic filtration at $5 \mu \mathrm{m}$. A tablet, calibrated for Lycopodium spores, is added to each sample at the start of the treatment in order to estimate the pollen concentration (Stockmarr, 1971). Taxonomic determinations are carried out using a Zeiss microscope under $\times 1000$ magnification. Identifications follow published pollen atlases (Reille, 1992; Ayyad and Moore, 1995; Beug, 2004) and pollen reference collections of the Prehistory Department of the Muséum National d'Histoire Naturelle and the Institut des Sciences de l'Evolution of Montpellier (ISEM). An average of 300 pollen grains are counted for each sample and then completed by research of entomogamous taxa that are common in arid regions and underrepresented in pollen assemblages (Horowitz, 1992; Carrión, 2002b).

The pollen-vegetation relationship and the climatic affinities of the pollen flora are established on the basis of specialised flora (Le Houérou, 1959, 1969, 1980, 1995; PottierAlapetite, 1979, 1981; Floret and Pontanier, 1982; Chaieb and Boukhris, 1998; Ozenda, 2004), completed by surface pollen spectra which are representative of the different regional environments (Jaouadi et al., 2016). The Amaranthaceae are a significant floristic component of the desert margins of southern Tunisia. Several botanic genera occupy either desert habitats or saline hollows along the coast. In order to separate the regional xerophytic from the local halophytic signal, the pollen morphology of the principal genera of desert Amaranthaceae in southern Tunisia (Anabasis, Cornulaca, Haloxylon and Traganum) has been studied with reference to the large ISEM reference collection and to previously published works (Nowicke, 1975; Nowicke and Skvarla, 1979; Salzmann and Schulz, 1995). Two pollen types have thus been distinguished: Amaranthaceaetype, which essentially groups together the halophytic taxa and Cornulaca/Traganum-type, which principally encompasses the xerophytic genera.

The pollen data are presented in the form of a simplified diagram of the most significant taxa grouped together in three ecological units, which are characteristic of the regional vegetation: mediterranean xerophytes, steppic herbaceous plants and desert herbaceous plants (Fig. 3). 
Table 1. Conventional AMS radiocarbon dates and reservoir-corrected and $2 \sigma$ range calibrated ages from Sebkha Boujmel (BJM2 core).

\begin{tabular}{lrcccccrr}
\hline Lab. code & $\begin{array}{c}\text { Depth } \\
(\mathrm{cm})\end{array}$ & $\begin{array}{c}\text { Conventional }{ }^{14} \mathrm{C} \\
\text { age }\end{array}$ & error & $\begin{array}{c}\text { Reservoir-corrected } \\
\text { age }\end{array}$ & $\begin{array}{c}\text { Lower } \\
\text { cal age }\end{array}$ & $\begin{array}{r}\text { Upper } \\
\text { cal age }\end{array}$ & $\begin{array}{r}\text { Mean age } \\
\text { cal yr BP }\end{array}$ & $\begin{array}{r}2 \sigma \\
\text { error }\end{array}$ \\
\hline BETA 403124 & 40 & 1570 & 30 & 1570 & 1395 & 1533 & 1464 & 98 \\
BETA 403123 & 75 & 2600 & 30 & 2200 & 2140 & 2315 & 2228 & 124 \\
BETA 384850 & 110 & 3450 & 30 & 3050 & 3174 & 3350 & 3262 & 124 \\
BETA 403122 & 120 & 3750 & 30 & 3350 & 3545 & 3643 & 3594 & 69 \\
POZ-75206 & 127 & 4305 & 35 & 3905 & 4237 & 4425 & 4331 & 133 \\
BETA 413550 & 134 & 5170 & 30 & 4770 & 5465 & 5589 & 5527 & 88 \\
POZ-75205 & 141 & 5985 & 35 & 5585 & 6300 & 6414 & 6357 & 81 \\
BETA 413551 & 146 & 5300 & 30 & 4900 & 5588 & 5663 & 5626 & 53 \\
BETA 403121 & 150 & 6640 & 30 & 6240 & 7153 & 7254 & 7204 & 71 \\
BETA 413552 & 156 & 7510 & 30 & 7110 & 7922 & 8000 & 7961 & 55 \\
BETA 384851 & 160 & 6370 & 30 & 5970 & 6730 & 6891 & 6811 & 114 \\
\hline
\end{tabular}

The percentages are calculated with respect to a basic sum that only includes these three groups. The percentages of aquatic, Amaranthaceae-type, long-range-transported, cultivated, nitrophilous and introduced taxa are calculated on the basis of a total sum of pollen grains identified within each pollen spectrum (Berglund and Ralska-Jasiewiczowa, 1986). Olea was not included in the basic sum and is included in the cultivated taxa as soon as its record coincides with that of the latter (Figs. 3 and 5). The wet/dry ratio (W/D) developed by Hooghiemstra (1996) is applied to Sebkha Boujmel pollen data (Fig. 4n) in order to trace the changes between the xerophytic herbaceous vegetation of the steppe and desert (dry amount: Asteraceae excluding Artemisia + Amaranthaceae Cornulaca/Traganumt.) and the steppic grasses that develop in more humid conditions (wet amount: Poaceae + Cyperaceae) (Hooghiemstra, 1996; Mercuri, 2008; Giraudi et al., 2013; Cremaschi et al., 2014).

The coherence and correlation between the ecological groups, the taxa used for the $\mathrm{W} / \mathrm{D}$ ratio, the pollen data and the clay mineralogical data, are provided by a correlogram reordered based on the first axis of the principal component analysis (Friendly, 2002). The processing of the pollen data is carried out using the Rioja package of the R software (R Core Team, 2013; Juggins, 2015). The local pollen zones (LPZs) are determined by visual observation of the pollen diagram and are validated by applying constrained hierarchical clustering by CONISS (Fig. 3) (Grimm, 1987). Long-term changes in the vegetation are represented by applying a cubic smoothing spline method to the data (Fig. 4).

\subsection{Clay mineralogy}

A total of 68 samples were subjected to qualitative and semiquantitative analysis of the clay fraction $(<2 \mu \mathrm{m})$ using X-ray diffraction. This procedure was carried out using a Bruker D4 Endeavor diffractometer coupled with a Lynxeye rapid detector fitted with a copper anticathode. The samples were prepared using a standard protocol (Bout-Roumazeilles et al., 1999). The samples are broken down in distilled water, decarbonated using $\mathrm{HCl} \mathrm{N} / 5$ and then deflocculated by repeated rinsing with distilled water. The suspensions obtained are placed in pill boxes and the micro-aggregates eliminated by a microhomogeniser. The granulometric fraction below $2 \mu \mathrm{m}$ is separated by collecting the upper part of the suspension after $1 \mathrm{~h} 15 \mathrm{~min}$ of decantation and is then centrifuged. Diffractometric analysis is carried out on three preparations: untreated, glycolated and heated. Clay mineral identification is carried out on the three preparations (Brindley and Brown, 1980). The semi-quantitative analysis is based on the integration of the signals for the main peaks of the clay minerals using the MacDiff software programme (Petschick, 2001).

\section{Results}

\subsection{Pollen data}

The pollen record for Sebkha Boujmel features good pollen grain preservation, with an average pollen concentration of ca. 35000 grains per $\mathrm{cm}^{-3}$, and wide taxonomic diversity with 114 pollen taxa being recorded.

For the Holocene, Sebkha Boujmel, which was fed by the Wadi Fessi, has revealed fluvial and aeolian pollen inputs from local and regional vegetation (Fig. 1b). Pinus is never overrepresented, indicating a moderate maritime influence and pollen inputs from a catchment area that is limited to the Jeffara Plain, the Matmata highlands and the desert margins. However, a few non-native pollen grains from the temperate regions of northern Africa and continental Europe (Alnus, Betula, Corylus, Carpinus/Ostrya, Cedrus and Myrica) have been identified throughout the sequence. These taxa, which are also recorded in other desert regions, demonstrate long-distance transportation of pollen by atmospheric circulation from the Mediterranean to the desert regions (Cour and Duzer, 1980; Schulz, 1984). In fact, the diversity in the pollen 


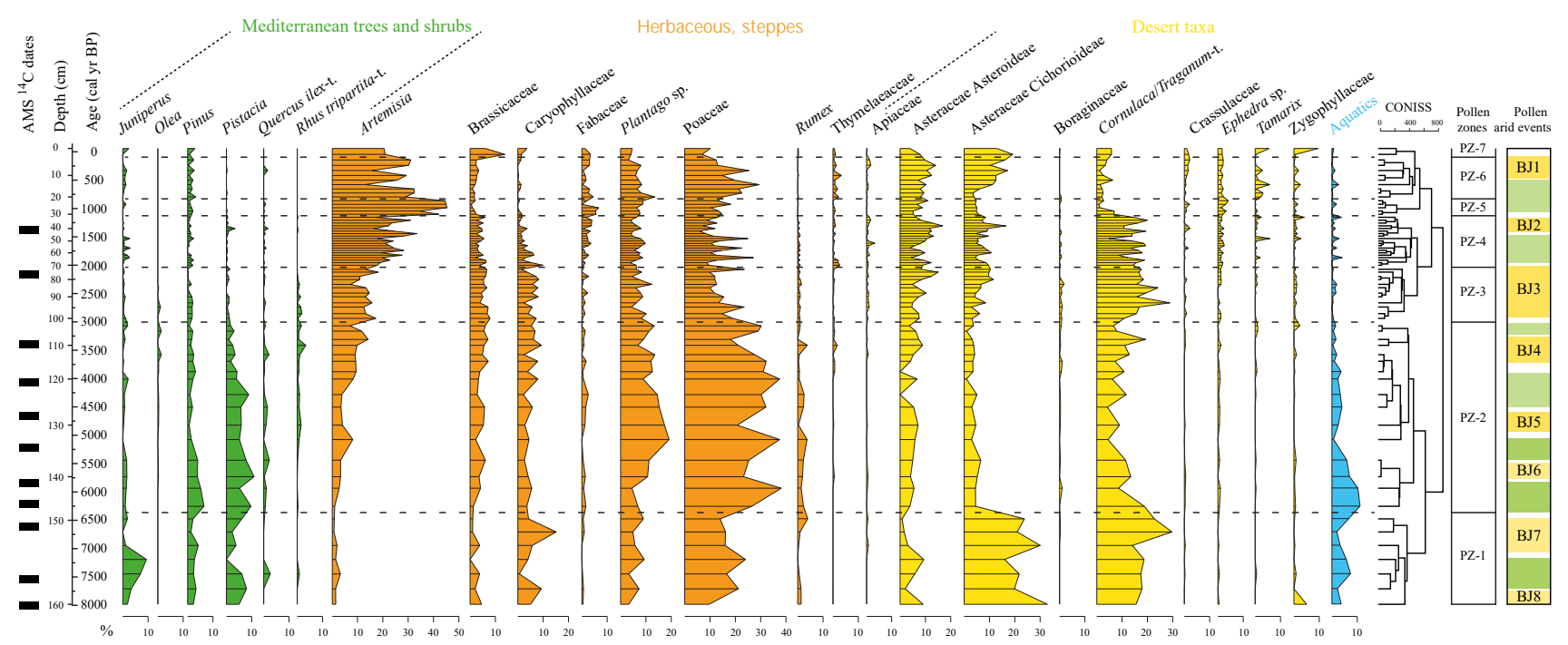

Figure 3. Pollen percentage diagram from Sebkha Boujmel showing the evolution of the main pollen taxa of the three ecological groups (Mediterranean, steppe and desert taxa) plotted against age. Pollen taxa and types from the same genus or family and with the same ecology are grouped on the pollen diagram, including Boraginaceae (Moltkiopsis ciliata, Onosma and Echium), Ephedra sp. (Ephedra fragilis-t. and Ephedra distachia-t.) and Zygophyllaceae (Fagonia, Nitraria and Zygophyllum). Percentage of aquatics pollen are calculated based on the total sum of pollen grains identified in each pollen spectrum. Black boxes on the depth scale indicate positions of ${ }^{14} \mathrm{C}$ AMS dates.

Table 2. Local pollen zones, vegetation, and inferred climatic and/or anthropogenic changes based on the pollen record from core BJM2.

\begin{tabular}{|c|c|c|c|c|c|}
\hline $\begin{array}{l}\text { Local pollen } \\
\text { zone (LPZ) }\end{array}$ & $\begin{array}{l}\text { Interval } \\
(\mathrm{cm})\end{array}$ & Age & LPZ description & Vegetation changes & $\begin{array}{l}\text { Inferred climate change and/or } \\
\text { anthropogenic impact }\end{array}$ \\
\hline LPZ-7 & $0-3$ & 2013-1855 AD & $\begin{array}{l}\text { Rise in cultivated (mainly } O l e a \text { ), nitrophilous and desert } \\
\text { taxa. Introduced taxa are recorded. High values of } \\
\text { Artemisia and decrease in Poaceae. }\end{array}$ & $\begin{array}{l}\text { Pre-desert steppes, degraded by agricul- } \\
\text { ture and pastoralism }\end{array}$ & $\begin{array}{l}\text { Environment greatly modified and de- } \\
\text { graded by humans }\end{array}$ \\
\hline LPZ-6 & $3-21$ & $95-827$ cal yr BP & $\begin{array}{l}\text { Artemisia, Fabaceae, Ephedra cultivated and ni- } \\
\text { trophilous taxa decrease. Increase in Cichorioideae, } \\
\text { Poaceae and some desert taxa. Cornulaca/Traganum-t., } \\
\text { Brassicaceae and Caryophyllaceae remain scarce. }\end{array}$ & $\begin{array}{l}\text { Mixed steppes with Artemisia and } \\
\text { Poaceae }\end{array}$ & $\begin{array}{l}\text { More humid climate evolving towards } \\
\text { aridity with limited anthropic impact }\end{array}$ \\
\hline LPZ-5 & $21-31$ & $827-1126$ cal yr BP & $\begin{array}{l}\text { Very high values of Artemisia (ca. } 45 \% \text { ) and increase } \\
\text { in Ephedra, Fabaceae, cultivated and nitrophilous taxa. } \\
\text { Decrease in Cornulaca/Traganum-t., Amaranthaceae, } \\
\text { Asteraceae, Brassicaceae and Caryophyllaceae. }\end{array}$ & $\begin{array}{l}\text { Pre-desert steppes with Artemisia, agri- } \\
\text { culture and pastoralism }\end{array}$ & $\begin{array}{l}\text { Slightly humid climate with significant } \\
\text { anthropic impact (pastoralism) }\end{array}$ \\
\hline LPZ-4 & $31-71$ & $1126-2026 \mathrm{cal} \mathrm{yr} \mathrm{BP}$ & $\begin{array}{l}\text { Increase in Artemisia, Ephedra, Asteraceae Aster- } \\
\text { oideae. Increase in cultivated taxa (Olea }+ \text { Vitis }) \text { and ni- } \\
\text { trophilous. High values for Cornulaca/Traganum-t. and } \\
\text { desert taxa. }\end{array}$ & Pre-desert steppes & $\begin{array}{l}\text { Arid climate with significant anthropic } \\
\text { impact (agriculture and pastoralism) }\end{array}$ \\
\hline LPZ-3 & $71-104$ & 2026-3122 cal yr BP & $\begin{array}{l}\text { Significant decrease in Poaceae and Rumex. Evident in- } \\
\text { crease in Artemisia, Cornulaca/Traganum-t., steppe and } \\
\text { desert taxa. First occurrence of cultivated taxa at ca } \\
2.3 \mathrm{ka} \text { BP. }\end{array}$ & Pre-desert steppes with Artemisia & $\begin{array}{l}\text { Arid climate with limited anthropic im- } \\
\text { pact }\end{array}$ \\
\hline LPZ-2 & $104-147$ & $3122-6366 \mathrm{cal}$ yr BP & $\begin{array}{l}\text { Increase in Pistacia, Pinus, Juniperus, Poaceae and } \\
\text { aquatics. Decrease in Cornulaca/Traganum-t. and } \\
\text { Caryophyllaceae. Low percentages of steppe and desert } \\
\text { herbaceous taxa. }\end{array}$ & $\begin{array}{l}\text { Mediterranean mattoral and grass } \\
\text { steppes, progressively evolving towards } \\
\text { pre-desert steppes }\end{array}$ & $\begin{array}{l}\text { Humid climate progressively evolving } \\
\text { towards arid climate }\end{array}$ \\
\hline LPZ-1 & $147-160$ & 6366-7982 cal yr BP & $\begin{array}{l}\text { Relatively high values for Pistacia, Juniperus, Quercus } \\
\text { ilex-t. Significant percentages of Asteraceae, Poaceae } \\
\text { and Cornulaca/Traganum-t. Low values of aquatic taxa } \\
\text { and Artemisia. }\end{array}$ & $\begin{array}{l}\text { Grass and desert steppes and Mediter- } \\
\text { ranean mattoral }\end{array}$ & $\begin{array}{l}\text { Arid climate with relative moisture in } \\
\text { favourable biotopes }\end{array}$ \\
\hline
\end{tabular}

assemblages from Sebkha Boujmel reflects the local steppic zones, the mountainous hinterland and the desert region.

Seven LPZs retrace the vegetation history in response to climate changes and the impact of human activity over the middle and late Holocene (Table 2, Fig. 3). The sequence from Sebkha Boujmel documents the landscape dynamic of southern Tunisia, from the Mediterranean shrublands to the pre-desert steppes on the uplands, as well as the spread of pre-desert steppes on the plains. These vegetation changes reflect the establishment of increasingly arid conditions since the middle Holocene, on top of which is added increasing human pressure over recent centuries (Table 2, Figs. 3 and $5)$. 


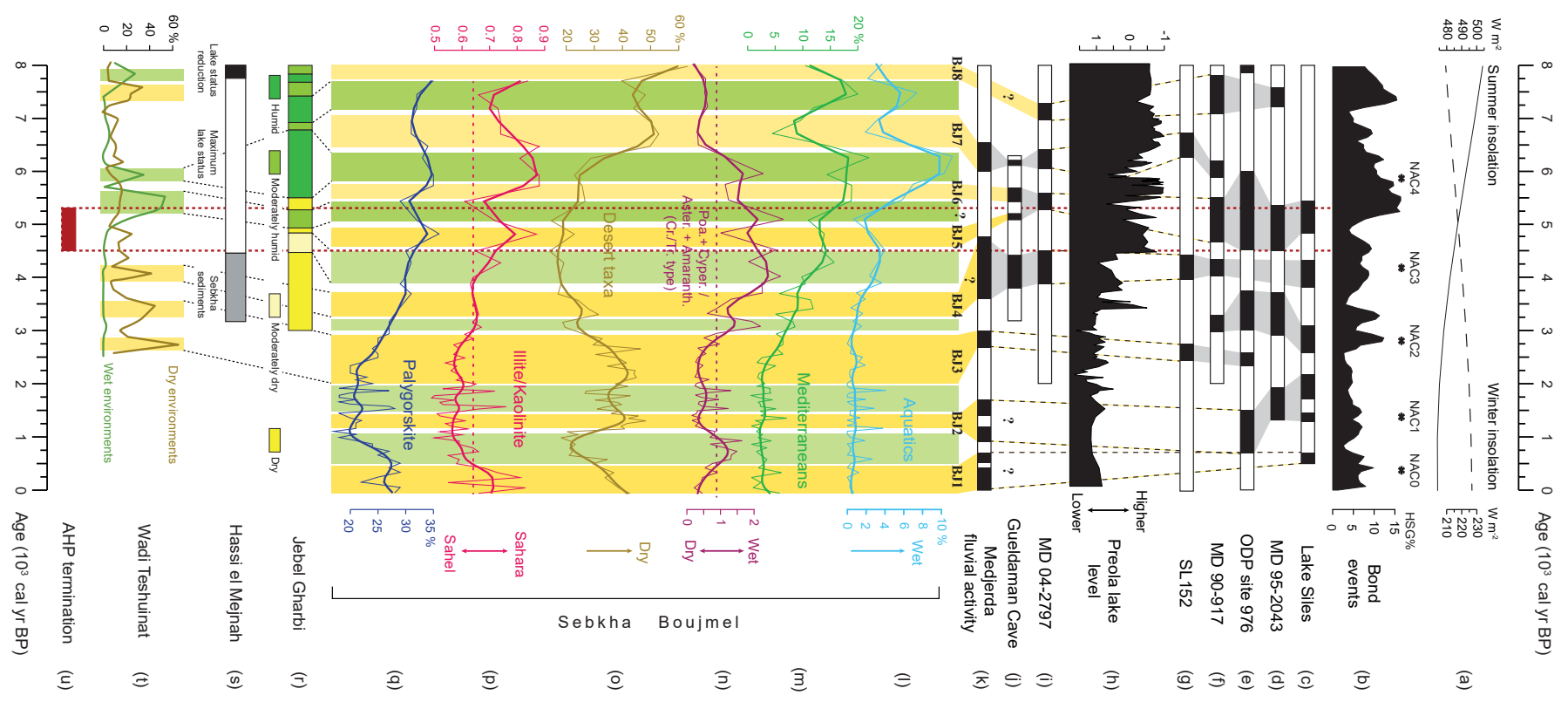

Figure 4. Comparison of pollen and clay mineralogy data from BJM2 core with paleoclimate records from the Mediterranean and the Sahara. (a) Summer (June mid-month) and winter (December mid-month) insolation ( $\mathrm{W} \mathrm{m}^{-2}$ ) curve at $30^{\circ} \mathrm{N}$ (Berger and Loutre, 1991). (b) Drift ice record from the North Atlantic: stacked percentage of HSG (hematite stained grains) of four records with stars indicate the North Atlantic cooling events (Bond et al., 2001; Bond et al., 1997). (c) Desiccation events at Lake Siles (southern Spain, $38^{\circ} 24^{\prime} \mathrm{N}, 2^{\circ} 30^{\prime} \mathrm{W}$ ) based on Pseudoschizaea microfossil abundance (Carrión, 2002a). (d) Episodes of Mediterranean forest decline based on pollen data from MD 952043 core in the Alboran Sea $\left(36^{\circ} 9^{\prime} \mathrm{N}, 2^{\circ} 37^{\prime} \mathrm{W}\right)$ (Fletcher et al., 2012).(e) Temperate forest decline events ODP site 976 core in the Alboran Sea $\left(36^{\circ} 12^{\prime} \mathrm{N}, 4^{\circ} 18^{\prime} \mathrm{W}\right)$ (Combourieu Nebout et al., 2009). (f) Cold and dry events on core MD 90-917 (41 $\left.{ }^{\circ} \mathrm{N}, 17^{\circ} 37^{\prime} \mathrm{E}\right)$ pollen record from the Adriatic Sea (Combourieu-Nebout et al., 2013). (g) Arid events from SL152 core (Aegean sea, 40 $19^{\prime}$ N, 24 $65^{\prime}$ E) $($ Kotthoff et al., 2008a, b; Schmiedl et al., 2010). (h) Lake-level fluctuations (CA scores) at Lago Preola in Sicily $\left(37^{\circ} 37^{\prime} \mathrm{N}, 12^{\circ} 38^{\prime} \mathrm{E}\right)(\mathrm{Magny}$ et al., 2011 ). (i) Identified arid spells on pollen data from MD 04-2797 core in the Siculo-Tunisian Strait $\left(36^{\circ} 57^{\prime} \mathrm{N}, 11^{\circ} 40^{\prime} \mathrm{E}\right)$ (Desprat et al., 2013). (j) Drought episodes based on stable isotopes record from stalagmite GLD1-stm4, Gueldaman Cave, N Algeria, (36 $\left.26^{\prime} \mathrm{N}, 4^{\circ} 34^{\prime} \mathrm{E}\right)\left(\mathrm{Ruan}^{\circ}\right.$ et al., 2016). (k) Phases of increased fluvial activity with low soil formation and arid climate in the Medjerda River valley, northern Tunisia (Faust et al., 2004; Zielhofer et al., 2004). Pollen and clay mineralogy data from Sebkha Boujmel (BJM2 core, $33^{\circ} 16^{\prime} \mathrm{N}^{\circ}, 11^{\circ} 05^{\prime} \mathrm{E}$ ) with bold lines showing the cubic smoothing splines and dashed lines averages for the I / K and W / D ratios. (l) Percentages of fresh water (Cyperaceae, Glyceria, Juncus, Lemna, Potamogeton, Rumex aquaticus-t., Typha/Sparganium-t.) and (m) Mediterranean tree and shrub (Buxus, Ceratonia, Cistus, Juniperus, Lamiaceae, Myrtus, Nerium, Olea, Papaveraceae, Pinus, Pistacia, Quercus ilex-t., Quercus deciduous-t., Rhus tripartita-t.) pollen taxa. (n) Wet / dry (W / D) pollen ratio (Poaceae + Cyperaceae/Asteraceae Cichorioideae + Asteraceae Asteroideae + Amaranthaceae Cornulaca/Traganum-t.). (o) Percentages of desert pollen taxa (Apiaceae, Asphodelus, Asteraceae Asteroideae, Asteraceae Cichorioideae, Calligonum, Capparis, Cistanche, Cleome, Cornulaca/Traganum-t., Crassulaceae, Cucurbitaceae, Echium, Ephedra distachia-t., Ephedra fragilis-t., Fagonia, Helianthemum, Malvaceae, Moltkiopsis ciliata, Neurada, Nitraria, Onosma, Reaumuria, Tamarix andZygophyllum). (p) Illite / kaolinite ratio and (q) palygorskite percentages. (r) Holocene climatic events in the Libyan Jeffara (Jebel Gharbi, north-western Libya, $32^{\circ} \mathrm{N}$ ) based on sedimentological and palynological data (Giraudi et al., 2013). (s) Paleohydrological changes at Hassi el Mejnah in Algeria $\left(31^{\circ} 14^{\prime} \mathrm{N}, 2^{\circ} 30^{\prime} \mathrm{E}\right)$ (Gasse, 2002; Hoelzmann et al., 2004). (t) Pollen data from rock shelters in the Wadi Teshuinat area (Tadrart Acacus Massif, central Sahara, south-west Libya $\left(24^{\circ} 30^{\prime}-26^{\circ} \mathrm{N}, 10-12^{\circ}\right.$ E; Cremaschi et al., 2014; Mercuri, 2008). (u) Estimated duration of the African Humid Period termination $(4.9 \mathrm{ka} \pm 400,2 \sigma)$ as indicated by aeolian dust flux data on marine sediment cores from the north-west African margin (McGee et al., 2013).

\subsection{Clay composition and origins}

Mineralogical analyses indicate that the clay fraction of the sediments is composed, on average, of $40 \%$ kaolinite, associated with $25 \%$ palygorskite and $25 \%$ illite. Chlorite and smectite are less abundant and represent 7 and $2 \%$ of the clay assemblage respectively. All clay minerals could have been transported to Sebkha Boujmel via aeolian processes or via the Wadi Fessi fluvial system. Both processes are rather irregular and are seasonally modulated by the precipitation regime. Illite mainly results from the process of physical erosion. It is often abundant in wind-blown particles and indicates a Saharan origin when it is associated with palygorskite (Foucault and Mélières, 2000; Goudie and Middleton, 2001). Palygorskite is a mineral that is typical of arid and semi-arid Mediterranean environments, which are characterised by alternating dry and humid periods. Palygorskite is a fibrous clay mineral abundant in wind-blown deposits and rare in river sediments since the elongated palygorskite particles are 


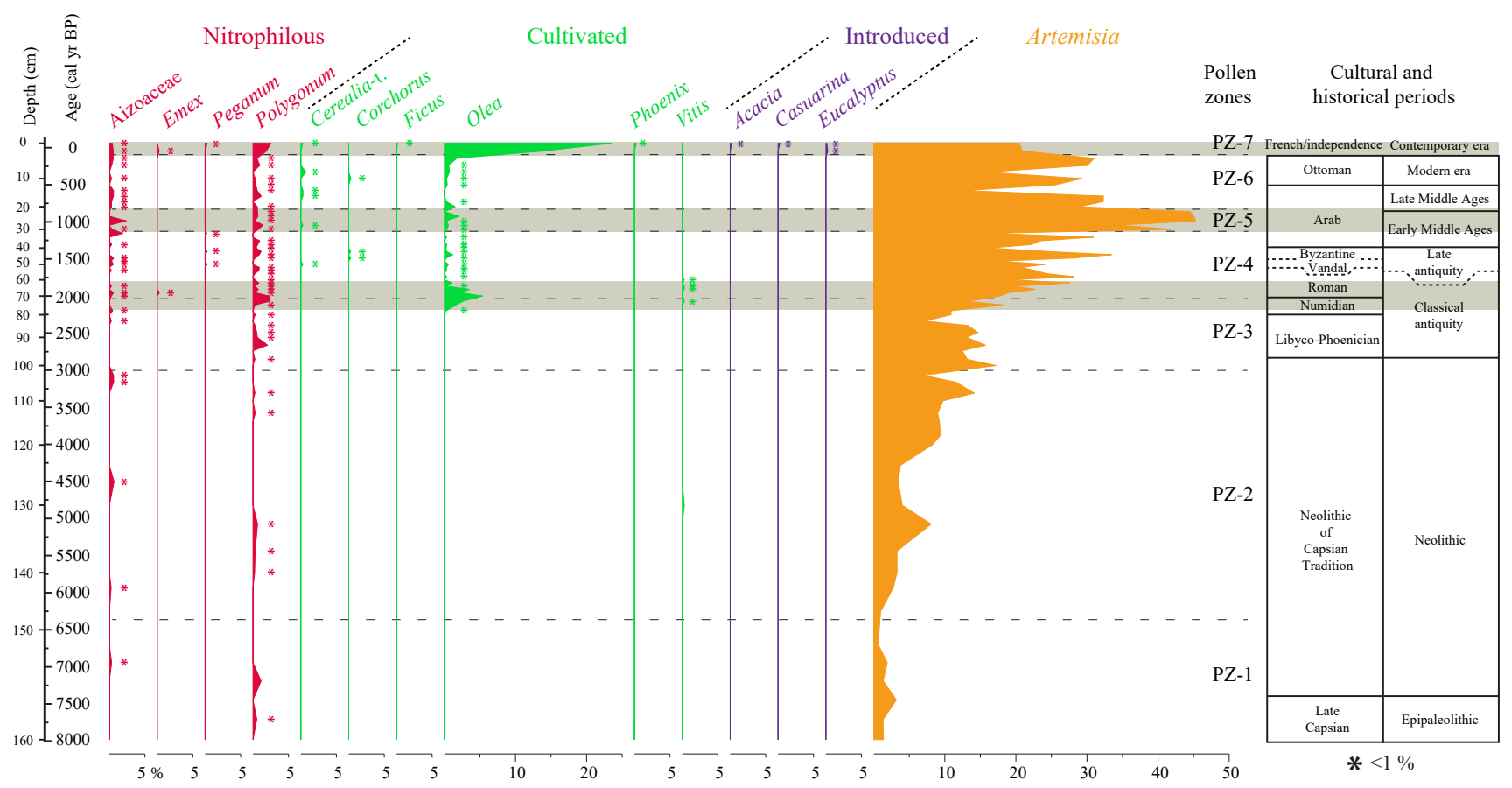

Figure 5. Detailed pollen diagram showing the evolution of Artemisia and selected anthropogenic pollen indicators (APIs) including cultivated (Cerealia-t., Corchorus, Ficus, Olea, Phoenix, Vitis), nitrophilous (Aizoaceae, Emex, Peganum, Polygonum) and introduced (Acacia cyanophylla-t., Casuarina, Eucalyptus) plant taxa. Grey bars highlight periods of enhanced human pastoral and/or agricultural activities. Table on the right side indicates the main cultural and historical subdivisions of Tunisian history.

easily broken during fluviatile transportation. It is abundant in northern Saharan desert dusts and in Tunisian dunes and loess, particularly Matmata loess (e.g. Coudé-Gaussen and Rognon, 1988; Bout-Roumazeilles et al., 2007). In northern Africa, kaolinite is more abundant in the central and southern Sahara, in Sahelian zones, where it is produced through intense hydrolysing processes, and in the eastern Sahara than in the western Sahara (e.g. Caquineau et al., 1998). As a result, an increase in the proportion of kaolinite at the expense of illite in the aeolian fraction suggests a dominant Sahelian origin for the clay particles (O'Hara et al., 2006; Hamann et al., 2009). The illite to kaolinite ratio (I / K) is, therefore, used to distinguish the respective contributions from Saharan and Sahelian sources in aeolian deposits (Fig. 4p) (e.g. Caquineau et al., 1998; Formenti et al., 2011). Comparison of the Sebkha Boujmel samples with those from northern African sands and sediments in terms of the $\mathrm{I} / \mathrm{K}$ ratio and the percentage of palygorskite indicates that the sediments are a mix of inputs from Tunisian loess ( $\mathrm{I} / \mathrm{K}=1.5$ and $45 \%$ palygorskite) and inputs from the Saharan zone (I / K $=0.4$ 2; 5-25\% palygorskite). The rather high I / $\mathrm{K}$ ratio observed in the Sebkha Boujmel sediments, ranging between 0.5 and 0.9 , rules out any major contribution from the Sahelian region ( $\mathrm{I} / \mathrm{K}=0.1$ ) but is consistent with mixed contributions from the south and central Sahara (I / K = 0.4) and the north or west Sahara (I / K $=s 0.5-0.7$, up to 2) (e.g. Caquineau et al., 1998).

\section{Discussion}

\subsection{Biogeography and Holocene palaeoenvironment in southern Tunisia}

Modern pollen rain from the vicinity of the sebkha and the mountainous hinterland tie in well with the regional biogeography. In these arid areas, the modern pollen spectra display a very low presence of Mediterranean taxa that require more humid conditions (Jaouadi et al., 2016). Today, only degraded relics of Mediterranean vegetation still survive on the wetter northern peaks of the Matmata Mountains (Le Houérou, 1959, 1969, 1995; Pottier-Alapetite, 1979, 1981; Chaieb and Boukhris, 1998). However, Mediterranean vegetation, and particularly Pistacia, appears to have been well developed at the beginning of the middle Holocene (Fig. 3). The uplands to the west of Sebkha Boujmel probably permitted the development of Mediterranean vegetation in southern Tunisia, alongside the Matmata Mountains at least as far as the latitude of Tataouine (Fig. 1b), during wetter climatic episodes. However, the Mediterranean vegetation did not extend as far as the mountainous areas of Libya further south. In the Libyan part of the Jeffara, the woody species that developed at Jbel Gharbi between 
9.4 and $5 \mathrm{ka} \mathrm{BP}$ constitute a desert-adapted shrubland formation (Capparis, Ficus, Salvadora persica and Tamarix) in which Mediterranean taxa remain poorly represented (Giraudi et al., 2013). Here the regional geographical features play an important role in limiting the southward progression of Mediterranean elements to the Tunisian Jeffara Plain because of their ecological requirements. Thus, the structure of the Mediterranean flora recorded at Sebkha Boujmel exhibits a significant xerophytic component, even during wetter periods, with Pinus, Juniperus and, in particular, Rhus tripartita, a Saharo-Mediterranean shrub. In addition, significant latitudinal spreads of Mediterranean vegetation may have occurred between central and southern Tunisia during favourable climatic episodes in the Holocene. The Holocene development of thermophilic bushland, with wild olive (Olea europaea subsp. europaea var. sylvestris) and pistachio (Pistacia lentiscus), is thus well documented in the Golfe de Gabès (Brun, 1992). The maximum extension of the Oleo-lentiscetum on the coast of the Golfe de Hammamet occurs at the $400 \mathrm{~mm}$ isohyet, which marks the limit of the semi-arid bioclimatic stage (Lebreton et al., 2015). At Sebkha Boujmel, Olea is recorded with low rates, reflecting a presence limited to the wettest biotopes. The Pistacia pollen taxon might correspond principally to $P$. atlantica. $P$. atlantica is more xerophytic than P. lentiscus and $O$. europaea subsp. europaea var. sylvestris, with a wider distribution, stretching from the sub-humid area to the Saharan area (Le Houérou, 1969). Moreover, its presence fits in well with the structure of the pollen flora recorded at Sebkha Boujmel.

Taking these biogeographical elements into account, over the course of the middle Holocene, the base of the sequence indicates an open landscape with grass steppe in the coastal lowlands and woody steppe, featuring Pistacia atlantica, Juniperus phoenicea and Rhus tripartita, on the foothills and along the waterways. Towards the north-west, the wetter highlands of the Matmata Mountains (Fig. 1b) would have been occupied by Pistacia lentiscus, Olea europaea subsp. europaea var. sylvestris and Cistus. It is also possible that Quercus ilex occurred towards the north on the more favourable mountain slopes. The regional landscape of the plain would have remained relatively open with herbaceous steppes, among which grass steppes were predominant. The arid phases are attested to in the development of xerophytic Amaranthaceae, while Artemisia, although present, is never very abundant during the middle Holocene.

\subsection{Mid- to late Holocene climate changes and landscape evolution}

\subsubsection{Aridity trend and the mid- to late Holocene transition}

Between ca. 5.7 and $4.6 \mathrm{kaBP}$, pollen data reveal a major shift towards the progressive establishment of steppic and pre-desert ecosystems, within which Mediterranean trees and shrubs play no role (Fig. 4). These environmental changes reflect the considerable impact of the climate during this period. A significant drop in humidity is recorded between ca. 5.7 and $4.6 \mathrm{kaBP}$, with two high-amplitude arid events (see Fig. 4, BJ6: 5.75-5.5 ka BP and BJ5: 4.9-4.6 ka BP). The abrupt decrease in pollen grains from aquatic plants reflects reduced precipitation associated with a reduction in permanent and/or seasonal water bodies (Fig. 4). Such drastic change is accompanied by a drop in the W / D (wet / dry) and I/K (illite / kaolinite) ratios, which attests to greater aridity and enhanced mobilisation of fine particles over long distances, probably from the central Sahara (Fig. 4). These arid events are of major significance because they occur during a period that was globally more humid. Subsequently, from about $4.5 \mathrm{kaBP}$ onwards, pollen data and clay mineralogy indicate short-term, wet climatic events that are, in fact, phases where there is a slight tendency towards greater humidity during a period which, on the whole, is drier (Fig. 4). These observations could alternately be interpreted as episodic pulses in the Wadi Fessi fluvial system. Following a return to relatively wet conditions around 4.5 to $4 \mathrm{ka} \mathrm{BP}$, aridity becomes progressively more pronounced from ca. $3.9 \mathrm{kaBP}$ onwards, with a continuous and irreversible decrease in the percentages of pollen grains from aquatic plants and Mediterranean species as well a drop in the $\mathrm{W} / \mathrm{D}$ and $\mathrm{I} / \mathrm{K}$ ratios (Fig. 4). The coeval decrease in the $\mathrm{I} / \mathrm{K}$ ratio and palygorskite content (from 35 to $20 \%$ ) suggests a decreased contribution of Tunisian loess and an enhanced contribution from the central Sahara.

Several records, from the Mediterranean and from the Sahara, reveal similarities with those from Sebkha Boujmel and indicate a significant trend towards aridification between ca. 5.7 and $4.6 \mathrm{kaBP}$ (Fig. 4). This dynamic is also evidenced at Chott Rharsa where a definitive drop in the water table was accompanied by renewed sand dune formation after 5.6 ka BP (Swezey et al., 1999; Swezey, 2001). In the Libyan part of the Jeffara Plain, a return of aeolian sedimentation occurs between 5.6 and $5.4 \mathrm{ka} \mathrm{BP}$, followed by the end of the humid period at around $5 \mathrm{kaBP}$ (Giraudi et al., 2013). On the northern margins of the Algerian Sahara, the definitive drying up of the Holocene palaeolakes, dated to ca. 5.2 ka BP (Callot and Fontugne, 2008), is followed by the formation of a calcareous crust between ca. 4.5 and $3 \mathrm{ka} \mathrm{BP}$ at Hassi el Mejnah (Gasse, 2000, 2002). Further south, the establishment of hyper-arid climate is evident in the pollen data from Wadi Teshuinat and the Takarkori rock shelters in the central Sahara between 5.7 and 4.6 ka BP (Mercuri, 2008; Cremaschi et al., 2014). Further north, in central Tunisia, significant changes in climatic conditions and ecosystems occur simultaneously with (1) the end of the growth phase of a stalagmite at La Mine Cave at ca. 5.6 ka BP (Genty et al., 2006), (2) the transition from a permanent to a temporary lake at Sebkha Kalbiyya after 6 ka BP (Boujelben, 2015) and (3) an arid episode between 5.5 and $5 \mathrm{ka} \mathrm{BP}$ associated with the development of Pistacia, based on pollen data from the 
Halk el Menjel sebkha lagoon (Lebreton and Jaouadi, 2013). A transition to arid climate is also revealed by isotopic data from Gueldaman Cave in northern Algeria, with a bipartite arid phase identified between 5.7 and $5.2 \mathrm{ka} \mathrm{BP}$ (Ruan et al., 2016). In the south-western Mediterranean, pollen and limnological data from Lake Siles in southern Spain also show a major phase of desiccation at around 5.4-4.8 ka BP (Carrión, 2002a). At the same time, between 5.5 and $4.5 \mathrm{ka} \mathrm{BP}$, a major arid phase is recorded in the sediments and marine cores from the Alboran Sea (Combourieu Nebout et al., 2009; Fletcher et al., 2012), the Adriatic Sea (Combourieu-Nebout et al., 2013) and the Siculo-Tunisian Strait (Desprat et al., 2013) (Fig. 4). In the eastern Mediterranean, synthesis of available climatic records also indicates a period of aridification beginning about $5.4 \mathrm{ka} \mathrm{BP}$ and culminating in complete aridity around $4.6 \mathrm{ka} \mathrm{BP}$ (Finné et al., 2011).

All of these contemporaneous events seem to indicate climatic mechanisms on the scale of the southern and eastern Mediterranean, with significant influence from the African monsoon. In the south, the desert zone is dominated by the seasonal northward shift of the Intertropical Convergence Zone (ITCZ) and of the African monsoon system. Furthermore, the latter is reinforced, from the early Holocene onwards, by a change in the orbital precession and an increase in summer insolation, which together give rise to the African Humid Period (AHP) (e.g. Kutzbach and Liu, 1997; deMenocal et al., 2000). However, there is still controversy about the date and amplitude of the end of the AHP. Some researchers opt for an abrupt end (deMenocal et al., 2000; McGee et al., 2013; Tierney and deMenocal, 2013), while others favour a gradual transition towards a hyper-arid climate (Gasse, 2002; Hoelzmann et al., 2004; Kröpelin et al., 2008; Lézine et al., 2011). The significant and rapid drop in humidity recorded in Sebkha Boujmel sediments between ca. 5.7 and $4.6 \mathrm{ka} \mathrm{BP}$ reflects a dynamic which is similar to the climatic history recorded in the Sahara and the abrupt end of the AHP between 5.3 and $4.5 \mathrm{kaBP}$ (McGee et al., 2013; Tierney and deMenocal, 2013). Furthermore, such a timing ties in with the rapid climate change (RCC), taking place between 6 and $5 \mathrm{kaBP}$, which marks the end of the humid period in tropical Africa (Mayewski et al., 2004) and greater climatic variability in the western Mediterranean (Fletcher and Zielhofer, 2013). Subsequent changes in the ecosystems and regional biogeography of southern Tunisia, such as those recorded at Sebkha Boujmel between ca. 4.5 and $3 \mathrm{kaBP}$, were progressive and reflect the different reactions of plant communities to the major changes in climatic conditions previously recorded between ca. 5.7 and $4.6 \mathrm{kaBP}$. Aquatic plants, for example, which are highly sensitive to changes in humidity, responded rapidly to these climatic changes, while Mediterranean and herbaceous species reacted more slowly due to their buffering capacity and/or their upland habitat.

However, this temporal similarity does not imply the direct influence of the low-latitude monsoon system and a tropical origin for the moisture recorded on the northern edges of the
Sahara over the course of the Holocene. In fact, the influence of the African monsoon never seems to have reached the Mediterranean coast (e.g. Arz et al., 2003; Tzedakis, 2007) and the stable isotope composition of groundwaters of the Great Eastern Erg suggests winter precipitation of a northern origin, which is comparable to present-day winter precipitation resulting from the southward shifting of the midlatitude westerlies (Gasse, 2002; Guendouz et al., 2003; Edmunds et al., 2004).

At Sebkha Boujmel, the humid-arid transition, which is contemporary with the end of the AHP, may have resulted from change in the configuration of global climatic drivers, particularly orbital parameters regulating insolation and Mediterranean atmospheric conditions. Changes in atmospheric and ocean circulation are mainly controlled by the Earth's orbital forcing (obliquity and precession), which acts on the climate system by controlling the seasonal and latitudinal distribution of insolation and temperature (e.g. Davis and Brewer, 2009; Brayshaw et al., 2010). Climate simulations indicate that enhanced seasonality of early Holocene insolation, with minimum precession and maximum obliquity, generates (i) an enhancement of the African monsoon and (ii) increased storm track activity and winter precipitation over the Mediterranean (Brayshaw et al., 2011; Kutzbach et al., 2014; Bosmans et al., 2015). According to Kutzbach et al. (2014), the influence of these orbital parameters (summer insolation maxima and winter insolation minima) could have generated a Holocene humid period in the Mediterranean, between 30 and $45^{\circ} \mathrm{N}$, by increasing both winter and summer precipitation. Furthermore, pollen-inferred precipitation values from Lake Trifoglietti and Lago di Pergusa in southern Italy also point to significant winter and summer precipitation during the humid phases of the early to mid-Holocene at latitudes south of $40^{\circ} \mathrm{N}$ (Peyron et al., 2013). During the changeover between the middle and late Holocene, the change in orbital parameters, and the weakening of the summer insolation, would, therefore, have led to a weakening of winter and summer storm tracks and more pronounced aridity over the southern Mediterranean, coeval with the end of the AHP.

\subsubsection{Holocene centennial-scale climate events in southern Tunisia since $8 \mathrm{ka}$ BP}

The pollen record of Sebkha Boujmel highlights eight aridity pulses that punctuate the middle and late Holocene. These dry events, numbered BJ8 to BJ1, occur at ca. 8-7.75, 7-6.5, $5.75-5.5,4.9-4.6,3.7-3.25,3-2,1.4-1.1$ and $0.4-0 \mathrm{kaBP}$ respectively and alternate with seven more humid phases (Fig. 4). The magnitude of the BJ8 arid event, at the base of the sequence, between ca. 8 and $7.75 \mathrm{ka} \mathrm{BP}$, could be associated with the $8.2 \mathrm{ka} \mathrm{BP}$ global event (Alley et al., 1997; Mayewski et al., 2004) and a significant instance of aridity recorded in the Mediterranean and at sites at the same latitude as Sebkha Boujmel, such as Sebkha Mellala (Gibert et 
al., 1990). Given the uncertainty regarding ${ }^{14} \mathrm{C}$ dates at the bottom of the sequence, BJ8 could be contemporaneous with the arid event recorded in various cores from the western (MD 95-2043) and central (MD 04-2797 and MD 90-917) Mediterranean, around 7.5 to $7 \mathrm{kaBP}$ (Fletcher et al., 2012; Combourieu-Nebout et al., 2013; Desprat et al., 2013).

The four subsequent arid phases (BJ7 to BJ4) may be connected with available data from further south in the Libyan Jeffara (Giraudi et al., 2013) and in the Sahara (Cremaschi et al., 2006; Mercuri, 2008; Cremaschi et al., 2014), particularly with the end of the AHP (Fig. 4). These events may also be linked to events recorded in the Mediterranean. In fact, numerous pollen records from the Mediterranean identify recurrent arid phases which are contemporaneous with North Atlantic cooling events (NAC) (Bond et al., 1997, 2001; Wanner et al., 2011). These dry episodes occur during the regression of Mediterranean plant groups and the increase in semi-desert associations in north-eastern Tunisia (Desprat et al., 2013) and are also evidenced by the decline of deciduous Quercus forest in Italy and Greece (Kotthoff et al., 2008a, b; Schmiedl et al., 2010; Combourieu-Nebout et al., 2013) and the western Mediterranean (Combourieu Nebout et al., 2009; Fletcher et al., 2010, 2012; Fletcher and Zielhofer, 2013). Such vegetation dynamics may be linked to colder and/or more arid climate (Combourieu Nebout et al., 2009, 2013; Desprat et al., 2013).

The $4.2 \mathrm{kaBP}$ event, separating the middle and late Holocene (Walker et al., 2012), is seen to be associated with the NAC 3 event, which is evident on the northern side of the Mediterranean Basin (Magny et al., 2009; Peyron et al., 2011), in the Siculo-Tunisian Strait (Desprat et al., 2013), in the Medjerda Valley (Faust et al., 2004; Zielhofer et al., 2004) and in the speleothems of Gueldaman Cave (Ruan et al., 2016). However, evidence for this event is not very clear in the Sebkha Boujmel record. Moreover, the 4.2 ka BP event is not recorded at core sites ODP 976 and MD 952043 (Fig. 4), nor is it recorded in the eastern Mediterranean (Finné et al., 2011). The last three arid episodes recorded in the Sebkha Boujmel sediments (BJ3, BJ2 and BJ1) are well correlated with the late Holocene NAC 2, NAC 1 and NAC 0 events respectively (Fig. 4).

The centennial-scale climatic events recorded in southern Tunisia from $8 \mathrm{kaBP}$ onwards may indicate a climatic coupling between the southern Mediterranean and the Sahara during the middle Holocene. Subsequently, in the late Holocene, and from $3 \mathrm{ka}$ BP onwards, atmospheric coupling was established with the North Atlantic. Significant changes in orbital, solar and ice-sheet climate forcing, as well as significant reorganisation of the global climate system and atmospheric circulation at the time of the mid- to late Holocene transition, might explain these modifications (Debret et al., 2009; Magny et al., 2013).

\subsection{Late Holocene landscape evolution and human impact}

Human impact has often been considered as overriding during the Holocene, shaping Mediterranean and Saharan landscapes under the effects of agriculture, pastoralism and vegetation clearance (Pons and Quézel, 1998; Schulz et al., 2009). In southern Tunisia, therefore, the vegetation landscape would be the result of significant human impact during the historical period, characterized by the degradation of previously more diverse natural vegetation, consisting of Mediterranean shrubby forest accompanied by tropical steppe with Acacia tortilis subsp. raddiana (Le Houérou, 1959, 1969; Frankenberg, 1986).

In arid environments, it is still difficult to distinguish between human and climatic factors solely on the basis of pollen analysis because several of the marker taxa for anthropisation belong to the natural vegetation of arid regions (Horowitz, 1992). However, in central and southern Tunisia, studies of the dynamics of pre-desert vegetation relevant to human activity, particularly pastoralism, allows nitrophilous and unpalatable taxa to be distinguished within the regional vegetation (Le Houérou, 1959, 1980; Tarhouni et al., 2010; Gamoun, 2014). Crossing the nitrophilous and unpalatable taxa with cultivated and introduced taxa allows the completion of the picture and the interpretation of anthropogenic indicators (Fig. 5).

\subsubsection{Landscape origin and human impact}

The Epipalaeolithic Capsian culture developed in the Maghreb during the Holocene, between ca. 10 and $7 \mathrm{kaBP}$, and was replaced by the Neolithic of Capsian Tradition (NCT) around $7 \mathrm{ka} \mathrm{BP} \mathrm{(Jackes} \mathrm{and} \mathrm{Lubell,} \mathrm{2008;} \mathrm{Mulazzani,}$ 2013). These cultural entities are largely distinguished on the basis of typological analysis of their lithic industries. However, in the Maghreb, the history of neolithisation and the emergence of a production economy are still not well understood. To date, very few studies have provided information on the anthropological and economic aspects of Holocene societies in the Maghreb and on human-environment interactions in this important period of cultural transition (Lubell et al., 1976; Roubet, 2003; Jackes and Lubell, 2008; Mulazzani, 2013). In Capéletti Cave (Aurès, Algeria), the NCT appeared around $7 \mathrm{kaBP}$, associated with a pastoral economy based on the rearing of sheep and goats (Roubet, 2003). Archaeological data from the Jeffara Plain and the Jebel Gharbi (Libya) attest to the development of the NCT from $8 \mathrm{kaBP}$, with pastoral encampments, typical NCT lithic industries and ceramics (Barich et al., 2006; Lucarini, 2013; Barich, 2014). Evidence suggests continuity in pastoral activities and transhumance in an area stretching from the foothills of Jebel Gharbi to the Jeffara Plain and on to the coast up until the historical period (Lucarini, 2013). In the environs of Sebkha Boujmel, rammadyats (open air sites), although damaged by 
recent human activity, are still visible and attest to Capsian and/or Neolithic occupation. The Holocene occupation of the region is also evident in the environs of the nearby Sebkha El Melah (Fig. 1c) where sites attributed to the NCT are dated to the 7th millennium cal BP (Perthuisot, 1975). Therefore, it appears that ecological niches formed by the paralic sebkhas were occupied and exploited by prehistoric communities during the Holocene period in central Tunisia. These communities hunted and exploited the ecosystems of the lagoons and coasts (Chenorkian et al., 2002; Zoughlami, 2009; Mulazzani, 2013).

At Sebkha Boujmel, human impact becomes evident after $3 \mathrm{kaBP}$ with the significant and ongoing appearance of nitrophilous taxa linked to pastoral practices (Fig. 5). No significant anthropogenic impact deriving from agricultural and/or pastoral activities has been recorded previously in the local ecosystems. At that time, the prehistoric societies had only a weak impact on the local environment. The emergence of present-day landscapes can, therefore, be correlated with important climate changes that occurred during the mid- to late Holocene transition. In fact, the presence of Mediterranean woodland vegetation in southern Tunisia is attested to at an early date, i.e. around $5 \mathrm{ka} \mathrm{BP}$, on the Île de Jerba (Damblon and Vanden Berghen, 1993). Mediterranean woody species are well represented between 8 and $5.5 \mathrm{ka} \mathrm{BP}$ in the pollen record from Sebkha Boujmel (Fig. 3). Such woodland formations are indicative of more humid climatic episodes up until $5.5 \mathrm{ka} \mathrm{BP}$ and the AHP termination, before the onset of increasing aridity. Therefore, in the late Holocene and during the historical period, the vegetation landscape of southern Tunisia was already a steppic- and semi-desert formation in which woodland formations were limited. The same vegetation structure can be observed in pollen data spanning the last 2 millennia from nearby Sebkha Mhabeul (Salzmann and Schulz, 1995; Marquer et al., 2008). The dynamic of vegetation associations revealed at Sebkha Boujmel before $3 \mathrm{kaBP}$, leaves no doubt regarding the primary role played by climate in the environmental changes that occurred during the middle and late Holocene. Nonetheless, an anthropogenic impact may have amplified the environmental changes of climatic origin during this period.

\subsubsection{Landscape evolution during historical periods}

Human impact increased over the last 3 centuries BC, during the historical period, with the continuous presence of nitrophilous taxa being recorded, testifying to the permanence of pastoral activities (Fig. 5). From this time onwards, the impact of agricultural activity becomes evident in the record with the addition of cultivated taxa, primarily Olea (Fig. 5). During the Libyo-Phoenician period, since at least the 5th century BC, there is evidence of a high level of human occupation with several urban settlements in the immediate environs of Sebkha Boujmel and Bahiret el Bibane (Fig. 1b) (Trousset and Paskoff, 1991; Drine, 1993; Mattingly, 1995).
While the Periplus of Pseudo-Scylax attests to the management of wild olive trees on the nearby Île de Jerba as early as the 4th century BC (Shipley, 2011), our data indicate actual cultivation of Olea on a large scale from the 3rd century BC onwards. Furthermore, the record for Vitis between the 2nd century BC and the 2nd century AD (Fig. 5) can be related to widespread cultivation of vines, the pollen of which does not disperse widely. Notwithstanding the arid and pre-desert environment, Vitis could have played an important role in the regional economy, particularly in the mountainous regions and in oases where suitable irrigation techniques would have allowed its development. Seed remains from the Garamantes oases in Fezzan (Libyan Sahara) attest to the cultivation of vines from the beginning of the first millennium BC (van der Veen, 1992; Mattingly et al., 2003), well before the consumption and/or introduction of other Mediterranean fruit crops (Punica granatum and Olea europaea subsp. europaea var. europaea) towards the end of the 1st millennium BC (Pelling, 2005).

In the surroundings of Sebkha Boujmel, the cultivation of olive trees remained relatively important throughout the first 2 centuries AD. However, a gradual decline in its cultivation is recorded from the beginning of the Roman period (Fig. 5). These changes may be related to the progressive decline in the economic and administrative importance of urban centres close to Sebkha Boujmel during the Roman period (46 BC to 429 AD), for example the cities of Zitha and Gergis (Mattingly, 1995). Furthermore, Roman oil presses have been discovered which display technical particularities that attest to low levels of local oil production and modest olive cultivation (Mrabet, 2011). From the 3rd century AD onwards, during the Vandal, Byzantine and early medieval periods, including the Arab conquest (from $670 \mathrm{AD}$ ), low percentages for cultivated plants indicate that agricultural activity was probably confined to the areas around Berber villages in the mountainous hinterland and that the lowlands were once again dominated by a pastoral economy.

The development of agricultural activities in south-eastern Tunisia between the 3 rd century BC and the 2 nd century AD coincides, in part, with a slightly more humid period which is recorded in the pollen and clay data between ca. 2 and $1.5 \mathrm{ka} \mathrm{BP}$ (50 BC to $450 \mathrm{AD}$ ) (Fig. 4). This episode, the Roman Humid Period (RHP), is also recorded at other sites. At Sebkha Mhabeul, for example, the RHP is associated with a phase of hydrological stability which ends around $430 \mathrm{AD}$ (Marquer et al., 2008). In the Medjerda Valley, the RHP coincides with a phase of stability and soil formation up until 1.7 ka BP (Faust et al., 2004). Further east, in the Dead Sea, the RHP is associated with an increase in precipitation (Neumann et al., 2010). A surge in agriculture associated with slightly more humid climate is also documented during the Roman period in other Mediterranean desert margins such as north-western Libya (Gilbertson et al., 1996), in Cyrenaica (Hunt et al., 2002) and at Wadi Faynan in southern Jordan (El-Rishi et al., 2007; Hunt et al., 2007). 
The data from Sebkha Boujmel indicate a return to arid climate between around 1.4 and $1.1 \mathrm{ka} \mathrm{BP}(\mathrm{BJ} 2$ : 550-850 AD), contemporary with the Dark Ages (DA) (Fig. 4). This phase is also marked by unstable climatic conditions, associated with a rise in the frequency and intensity of flood events from $550 \mathrm{AD}$ onwards and of arid conditions up to $950 \mathrm{AD}$ at Sebkha Mhabeul (Marquer et al., 2008) and by a renewal of river activity in the Medjerda Valley (Faust et al., 2004).

Between about 1.1 and $0.5 \mathrm{kaBP}$ (850-1450 AD), the $\mathrm{W} / \mathrm{D}$ ratio as well as a drop in herbaceous desert plants indicate a humid period in southern Tunisia, which, while of modest magnitude, was more important than that recorded during the RHP (Fig. 4). Associated with these wetter conditions, a significant peak in Artemisia occurs between ca. 1.1 and $0.8 \mathrm{kaBP}$ (850-1150 AD) (Table 2, LPZ5 and Fig. 5), which essentially corresponds to the Medieval Climate Anomaly (MCA). However, it is still difficult to interpret these very high Artemisia values, which also feature in the pollen data for the Golfe de Gabès (Brun and RouvilloisBrigol, 1985), as solely reflecting a change in climate. In fact, during the various humid-arid episodes identified between 8 and $4 \mathrm{ka} \mathrm{BP}$, Mediterranean and desert taxa fluctuate significantly but wormwood does not (Figs. 3, 5). In addition, Artemisia does not develop in the Sahara (Ritchie et al., 1985; Ritchie and Haynes, 1987; Lézine et al., 2011), nor on the Île de Jerba (Damblon and Vanden Berghen, 1993) during the early and middle Holocene. Therefore, Artemisia had only a limited presence in the vegetation groups of the southern Tunisian desert margins, which instead were dominated by grassy steppes and which were in direct contact with desert ecosystems (Amaranthaceae) over the course of the early and middle Holocene. In the same period, Artemisia was well developed further north in central Tunisia (Lebreton and Jaouadi, 2013). Its significant development, associated with that of nitrophilous taxa in southern Tunisia during the late Holocene, was probably, therefore, linked to human activity and, in particular, to pastoralism. In fact, with the exception of Artemisia herba-alba, the other species of Artemisia, such as A. campestris, are not particularly palatable and are avoided by grazing animals (Le Houérou, 1980; Tarhouni et al., 2010; Gamoun, 2014). In fact, studies of the dynamics of current steppic vegetation indicate that Artemisia campestris is a pioneer species in its occupation of Rhanterium suaveolens sandy steppes which have been degraded by vegetation clearance and over-grazing on the Jeffara Plain (Chaieb and Zaâfouri, 2000; Genin et al., 2006). Furthermore, historically this period (LPZ5; 850 to $1150 \mathrm{AD})$ corresponds to a period of climate instability with a succession of droughts and famines inducing a decline in the urban and economic structure of the Maghreb. A substantial shift towards pastoralism was also favoured by the migration of nomadic Banu Hilal tribes from southern Egypt to northern Africa during the 11th century AD (Allaoua, 2003). Thus, at Sebkha Boujmel, the development of Artemisia during the late Holocene, and particularly between ca. 1.1 and
$0.8 \mathrm{ka} \mathrm{BP}$, may have resulted from a combination of several factors including deterioration in plant diversity under the pressure of intense pastoral activity and an unstable climate with significant seasonal and/or multi-year contrasts.

The humid period recorded at Sebkha Boujmel between ca. 1.1 and $0.5 \mathrm{kaBP}$ (850-1450 AD), and associated with the MCA, is followed between ca. 450 and $95 \mathrm{cal}$ yr BP (BJ1, 1500-1855 AD) by a drop in the $\mathrm{W} / \mathrm{D}$ ratio and the progression of desert taxa (Fig. 4). Arid conditions are re-established in southern Tunisia and are contemporary with the Little Ice Age (LIA, ca. 1450-1850 AD). This arid climatic episode during the LIA coincides with an increase in clastic deposits at the top of the sedimentary fill from nearby Sebkha Mhabeul (Marquer et al., 2008) and the renewal of river activity in the Medjerda Valley (Faust et al., 2004) and is also contemporary with the most recent Bond event (NAC 0) at around $0.4 \mathrm{kaBP}$ (Fig. 4). This succession of wet/dry climatic conditions, which occurred during the MCA-LIA transition in southern Tunisia, is also evident in other palaeoecological records from around the Mediterranean Basin, particularly in sedimentary sequences from caves in Cyrenaica (Hunt et al., 2010, 2011) and Wadi Faynan in Jordan (Hunt et al., 2007), in pollen data from the coast of northern Syria (Kaniewski et al., 2011) and from the Dead Sea (Neumann et al., 2010), and in Siles Lake in southern Spain (Carrión, 2002a). However, in the western and central Mediterranean, several proxies reveal a reversed succession of climatic conditions, with an arid climate during the MCA and more humid conditions during the LIA. In the central Mediterranean, this climate trend is recorded in the pollen data from Lago di Pergusa in Sicily (Sadori et al., 2016) and at Lago di Venere on the island of Pantelleria (Calò et al., 2013). For the western Mediterranean, these climatic conditions (i.e. arid during the MCA and humid during the LIA) are evident in dendroclimatological data obtained from Cedrus atlantica in northern Morocco (Esper et al., 2007), in multi-proxy data from Lake Zoñar in southern Spain (Martín-Puertas et al., 2008) and in marine cores from the Alboran Sea (Nieto-Moreno et al., 2013).

In fact, over the course of the last millennium, the MCA (900-1350 AD) and the LIA (1500-1850 AD) climatic episodes exhibit significant anomalies in temperature and atmospheric circulation in the Northern Hemisphere which could have been triggered by changes in solar irradiance (Mann et al., 2009; Graham et al., 2011; Swingedouw et al., 2011). Data from Morocco and Spain indicate a strong correlation between arid-humid variability and positive-negative modes of the North Atlantic Oscillation (NAO; Esper et al., 2007; Martín-Puertas et al., 2008; Trouet et al., 2009; NietoMoreno et al., 2013; Wassenburg et al., 2013). Over the course of the MCA and LIA, the marked regionalisation as well as the divergent responses between the central and western Mediterranean on the one hand and the southern and eastern Mediterranean on the other may reflect the greater impact of the NAO on storm tracks in the northern and western 
Mediterranean (Trigo et al., 2004; Trouet et al., 2009). The Mediterranean expression of the NAO, the Mediterranean Oscilliation (MO), could have driven the contrasts revealed in the palaeoecological records because it would have generated pressure and hydrological contrasts between northwestern and south-eastern Mediterranean areas (Dünkeloh and Jacobeit, 2003).

\subsubsection{Current landscape degradation and desertification processes}

The past century has witnessed profound change in the regional ecosystems of southern Tunisia (Fig. 5). Desert taxa are proliferating around Sebkha Boujmel, as are other anthropogenic indicators which reflect the increasing impact of human activities on the environment (Fig. 5). Thus, for example, recently introduced xenophytic taxa, such as $\mathrm{Ca}$ suarina, Acacia cyanophylla and Eucalyptus are present in the Sebkha Boujmel pollen record. Olive growing is becoming more and more developed, and the rise in Olea is paralleled by the records for other cultivated taxa (Phonix and Cerealia) (Fig. 5). Pastoralism is indicated by ruderal and nitrophilous taxa (Peganum, Polygonum) and by the more common occurrence of the pollen taxa Tamarix, Thymelaea and those of the Zygophyllaceae family (Nitraria, Fagonia and Zygophyllum) (Figs. 3 and 5). The latter plants, which usually show a preference for desert conditions, are unpalatable and resistant to grazing (Le Houérou, 1980; Tarhouni et al., 2010; Gamoun, 2014). Their development, therefore, reflects deterioration in vegetation cover due to overgrazing, which actually favours their spread. Radical changes in the relationships between humans and the environment are thus recorded in south-eastern Tunisia, particularly in the pollen sequence from Sebkha Boujmel. In the Jeffara coastal plain, the traditional economy up until the end of the 19th century was based on extensive pastoralism, ensuring the mobility of people and their herds. At this time, the anthroposystem was relatively balanced in the context of the limited, fragile resources (Talbi, 1997). After 1881 AD, under the French protectorate, these traditional social and production structures were suppressed in favour of increased sedentism and the introduction of new systems of agricultural production based on individual ownership of land and intensive olive and cereal production (Abaab, 1986). These economic and social changes resulted in increased impacts on the environment (Talbi et al., 2009). In fact, the disappearance of collective herd management led to a reduction in herd movements and caused locally intensive overgrazing with rapid deterioration of vegetation cover accompanied by an increase in unpalatable substitute species. All of these changes led to an accentuation of wind and water erosion and an intensification of the process of desertification (Sghaier et al., 2012).

\section{Conclusions}

Pollen and clay mineralogical data from Sebkha Boujmel underline the significant potential of salt-flat sedimentary records as palaeoecological archives. Sebkhas are particularly conducive to the preservation of pollen in arid regions and, therefore, constitute a rare sedimentary resource favourable to palynology in subarid environments and allowing the reconstruction of the dynamics of vegetal environments. Pollen data from Sebkha Boujmel provide the first, continuous, high-resolution record to allow the detailed reconstruction of the landscape dynamics of southeastern Tunisia over the last 8 millennia. The palaeoecological records from Sebkha Boujmel tie in with other regional and extra-regional proxies and the impact of global climate changes can be superimposed on local conditions with various degrees of sensitivity. These events highlight the complexity of climatic trajectories in the south-central Mediterranean, with the influence of several closely correlated parameters, such as solar forcing and NAO-type circulation, from ca. $8 \mathrm{ka}$ BP onwards. Furthermore, the vegetation dynamic suggests that human activity could have amplified the arid climatic event which began in the late Holocene. The anthropogenic impact became predominant when a sedentary way of life developed, i.e. during classical antiquity and, later, under the French protectorate. In the case of the latter period, spanning the last century, anthropogenic changes become evident and have led to profound alterations to the spatial organisation of the territory. The pronounced development of desert taxa and markers of agricultural and pastoral activity, attest to fundamental changes in the relationships between humans and the environment in southern Tunisia at the present time. The joint impact of climate change and human pressure results in a drastic deterioration of the landscape by accentuating the process of desertification.

Acknowledgements. The authors wish to thank the Institut National du Patrimoine de Tunis (INP), which organised the fieldwork and provided necessary authorisation and logistical support for coring and for the archaeological survey of the environs of Sebkha Boujmel. This research was financially supported by the European Commission within the framework of the Erasmus Mundus International Doctorate in Quaternary and Prehistory (IDQP) coordinated by the Università degli studi di Ferrara (Italy). This work was part-funded by the Tunisian Minister for Higher Education and Scientific Research and by the Mistrals-PaleoMex programme.

Edited by: J. Guiot

\section{References}

Abaab, A.: Mutations socio-économiques de la Jeffara orientale (Sud tunisien), Revue de l'Occident musulman et de la Méditerranée, 43, 327-338, 1986. 
Allaoua, A.: Retour à la problématique du déclin économique du monde musulman médiéval: le cas du Maghreb Hammadide (XXIIe siècle), The Maghreb Review, 28, 2-26, 2003.

Alley, R. B., Mayewski, P. A., Sowers, T., Stuiver, M., Taylor, K. C., and Clark, P. U.: Holocene climatic instability: A prominent, widespread event 8200 yr ago, Geology, 25, 483486, doi:10.1130/0091-7613(1997)025<0483:hciapw> 2.3.co;2, 1997.

Arz, H. W., Lamy, F., Pätzold, J., Müller, P. J., and Prins, M.: Mediterranean Moisture Source for an Early-Holocene Humid Period in the Northern Red Sea, Science, 300, 118-121, 2003.

Ayyad, S. M. and Moore, P. D.: Morphological studies of the pollen grains of the semi-arid region of Egypt, Flora, 190, 115-133, 1995.

Azuara, J., Combourieu-Nebout, N., Lebreton, V., Mazier, F., Müller, S. D., and Dezileau, L.: Late Holocene vegetation changes in relation with climate fluctuations and human activity in Languedoc (southern France), Clim. Past, 11, 1769-1784, doi:10.5194/cp-11-1769-2015, 2015.

Ballais, J.-L.: Évolution holocène de la Tunisie saharienne et présaharienne, Méditerranée, 31-38, 1991.

Ballais, J. L. and Ouezdou, H. B.: Forms and deposits of the continental quaternary of the Saharan margin of Eastern Maghreb (tentative synthesis), J. Afr. Earth Sci., 12, 209-216, doi:10.1016/0899-5362(91)90070-F, 1991.

Barich, B. E.: Northwest Libya from the early to late Holocene: New data on environment and subsistence from the Jebel Gharbi, Quatern. Int., 320, 15-27, doi:10.1016/j.quaint.2013.09.007, 2014.

Barich, B. E., Garcea, E. A. A., and Giraudi, C.: Between the Mediterranean and the Sahara: geoarchaeological reconnaissance in the Jebel Gharbi, Libya, Antiquity, 80, 567-582, doi:10.1017/S0003598X00094047, 2006.

Berger, A. and Loutre, M. F.: Insolation values for the climate of the last 10 million years, Quaternary Sci. Rev., 10, 297-317, doi:10.1016/0277-3791(91)90033-Q, 1991.

Berglund, B. E. and Ralska-Jasiewiczowa, M.: Pollen analysis and pollen diagrams, in: Handbook of Holocene Palaeaecology and Palaeohydrology, edited by: Berglund, B. E., John Wiley \& Sons, 455-484, 1986.

Berndtsson, R.: Topographical and coastal influence on spatial precipitation patterns in Tunisia, Int. J. Climatol., 9, 357-369, doi:10.1002/joc.3370090403, 1989.

Beug, H.-J.: Leitfaden der Pollenbestimmung für Mitteleuropa und angrenzende Gebiete, Verlag Dr. Friedrich Pfeil, München, 2004.

Blaauw, M.: Methods and code for "classical" age-modelling of radiocarbon sequences, Quat. Geochronol., 5, 512-518, doi:10.1016/j.quageo.2010.01.002, 2010.

Blaauw, M. and Heegaard, E.: Estimation of Age-Depth Relationships, in: Tracking Environmental Change Using Lake Sediments, edited by: Birks, H. J. B., Lotter, A. F., Juggins, S., and Smol, J. P., Developments in Paleoenvironmental Research, Springer, the Netherlands, 379-413, 2012.

Bond, G., Showers, W., Cheseby, M., Lotti, R., Almasi, P., deMenocal, P., Priore, P., Cullen, H., Hajdas, I., and Bonani, G.: A Pervasive Millennial-Scale Cycle in North Atlantic Holocene and Glacial Climates, Science, 278, 1257-1266, doi:10.1126/science.278.5341.1257, 1997.
Bond, G., Kromer, B., Beer, J., Muscheler, R., Evans, M. N., Showers, W., Hoffmann, S., Lotti-Bond, R., Hajdas, I., and Bonani, G.: Persistent Solar Influence on North Atlantic Climate During the Holocene, Science, 294, 2130-2136, doi:10.1126/science.1065680, 2001.

Bosmans, J. H. C., Drijfhout, S. S., Tuenter, E., Hilgen, F. J., Lourens, L. J., and Rohling, E. J.: Precession and obliquity forcing of the freshwater budget over the Mediterranean, Quaternary Sci. Rev., 123, 16-30, doi:10.1016/j.quascirev.2015.06.008, 2015.

Boujelben, A.: L'hydrosystème des sebkhas al Kalbiyya et Halq al Minjil: Dynamiques hydro-morphosédimentaires, paléoenvironnements et évolution des paysages pendant l'Holocène, $\mathrm{PhD}$, Université de Tunis I, Faculté des Sciences Humaines et Sociales and Université de Caen, UFR Géographie, 347 pp., 2015.

Bout-Roumazeilles, V., Cortijo, E., Labeyrie, L., and Debrabant, P.: Clay mineral evidence of nepheloid layer contributions to the Heinrich layers in the northwest Atlantic, Palaeogeogr. Palaeocl., 146, 211-228, doi:10.1016/S0031-0182(98)00137-0, 1999.

Bout-Roumazeilles, V., Combourieu Nebout, N., Peyron, O., Cortijo, E., Landais, A., and Masson-Delmotte, V.: Connection between South Mediterranean climate and North African atmospheric circulation during the last 50,000 yr BP North Atlantic cold events, Quaternary Sci. Rev., 26, 3197-3215, doi:10.1016/j.quascirev.2007.07.015, 2007.

Brayshaw, D. J., Hoskins, B., and Black, E.: Some physical drivers of changes in the winter storm tracks over the North Atlantic and Mediterranean during the Holocene, Philos. T. R. Soc. S.-A, 368, 5185-5223, doi:10.1098/rsta.2010.0180, 2010.

Brayshaw, D. J., Rambeau, C. M. C., and Smith, S. J.: Changes in Mediterranean climate during the Holocene: Insights from global and regional climate modelling, The Holocene, 21, 1531, doi:10.1177/0959683610377528, 2011.

Brindley, G. W. and Brown, G.: Crystal Structures of Clay Minerals and Their X-ray Identification, Mineralogical Society, London, 1980.

Brun, A.: Etude palynologique des sédiments marins holocènes de 5000 B.P. à l'actuel dans le golfe de Gabès (Mer Pélagienne), Pollen et Spores, 25, 437-460, 1983.

Brun, A.: Pollens dans les séries marines du Golfe de Gabès et du plateau des Kerkennah (Tunisie): signaux climatiques et anthropiques, Quaternaire, 3, 31-39, 1992.

Brun, A. and Rouvillois-Brigol, M.: Apport de la palynologie à l'histoire du peuplement en Tunisie, in: Palynologie archéologique, CNRS, Paris, 213-226, 1985.

Callot, Y. and Fontugne, M.: Les sites lacustres d'âge holocène dans l'est du Grand Erg occidental (nord-ouest du Sahara algérien): interprétation géomorphologique et paléoclimatique, Géomorphologie, 3, 187-200, doi:10.4000/geomorphologie.7173, 2008.

Calò, C., Henne, P. D., Eugster, P., van Leeuwen, J., Gilli, A., Hamann, Y., La Mantia, T., Pasta, S., Vescovi, E., and Tinner, W.: 1200 years of decadal-scale variability of Mediterranean vegetation and climate at Pantelleria Island, Italy, The Holocene, 23, 1477-1486, doi:10.1177/0959683613493935, 2013.

Caquineau, S., Gaudichet, A., Gomes, L., Magonthier, M.-C., and Chatenet, B.: Saharan dust: Clay ratio as a relevant tracer to assess the origin of soil-derived aerosols, Geophys. Res. Lett., 25, 983-986, doi:10.1029/98GL00569, 1998. 
Carrión, J. S.: Patterns and processes of Late Quaternary environmental change in a montane region of southwestern Europe, Quaternary Sci. Rev., 21, 2047-2066, doi:10.1016/S02773791(02)00010-0, 2002a.

Carrión, J. S.: A taphonomic study of modern pollen assemblages from dung and surface sediments in arid environments of Spain, Rev. Palaeobot. Palyno., 120, 217-232, doi:10.1016/S00346667(02)00073-8, 2002b.

Chaieb, M. and Boukhris, M.: Flore succinte et illustrée des zones arides et sahariennes de Tunisie, Association pour la protection de la nature et de l'environnement, 290 pp., 1998.

Chaieb, M. and Zaâfouri, M. S.: L'élevage extensif, facteur écologique primordial de la transformation physionomique du cortège floristique en milieu steppique tunisien, in: Rupture : nouveaux enjeux, nouvelles fonctions, nouvelle image de l'élevage sur parcours, edited by: Bourbouze, A. and Qarro, M., CIHEAM, Montpellier, 217-222, 2000.

Chenorkian, R., Harbi-Riahi, M., and Zoughlami, J.: Atlas Préhistorique de la Tunisie, 19, Maharès, École Française de Rome, 2002.

Combourieu Nebout, N., Peyron, O., Dormoy, I., Desprat, S., Beaudouin, C., Kotthoff, U., and Marret, F.: Rapid climatic variability in the west Mediterranean during the last 25000 years from high resolution pollen data, Clim. Past, 5, 503-521, doi:10.5194/cp5-503-2009, 2009.

Combourieu-Nebout, N., Peyron, O., Bout-Roumazeilles, V., Goring, S., Dormoy, I., Joannin, S., Sadori, L., Siani, G., and Magny, M.: Holocene vegetation and climate changes in the central Mediterranean inferred from a high-resolution marine pollen record (Adriatic Sea), Clim. Past, 9, 2023-2042, doi:10.5194/cp9-2023-2013, 2013.

Coudé-Gaussen, G. and Rognon, P.: The upper pleistocene loess of southern Tunisia: A statement, Earth Surf. Proc. Land., 13, 137151, doi:10.1002/esp.3290130205, 1988.

Cour, P. and Duzer, D.: Action actuelle des courants atmosphériques sur la dissémination des pollens au Sahara et dans les régions climatiques avoisinantes le long d'un transect Oran-Abidjan, in: Palynologie et climats, Mém. Mus. Nat. Hist. Nat., Paris, 66-81, 1980.

Cremaschi, M., Pelfini, M., and Santilli, M.: Cupressus dupreziana: a dendroclimatic record for the middle-late Holocene in the central Sahara, The Holocene, 16, 293-303, doi:10.1191/0959683606h1926rr, 2006.

Cremaschi, M., Zerboni, A., Mercuri, A. M., Olmi, L., Biagetti, S., and di Lernia, S.: Takarkori rock shelter (SW Libya): an archive of Holocene climate and environmental changes in the central Sahara, Quaternary Sci. Rev., 101, 36-60, doi:10.1016/j.quascirev.2014.07.004, 2014.

Damblon, F. and Vanden Berghen, C.: Etude paléo-écologique (pollen et macrorestes) d'un dépôt tourbeux dans l'île de Djerba, Tunisie méridionale, Palynosciences, 2, 157-172, 1993.

Davis, B. S. and Brewer, S.: Orbital forcing and role of the latitudinal insolation/temperature gradient, Clim. Dynam., 32, 143-165, doi:10.1007/s00382-008-0480-9, 2009.

Debret, M., Sebag, D., Crosta, X., Massei, N., Petit, J. R., Chapron, E., and Bout-Roumazeilles, V.: Evidence from wavelet analysis for a mid-Holocene transition in global climate forcing, Quaternary Sci. Rev., 28, 2675-2688, doi:10.1016/j.quascirev.2009.06.005, 2009.
deMenocal, P., Ortiz, J., Guilderson, T., Adkins, J., Sarnthein, M., Baker, L., and Yarusinsky, M.: Abrupt onset and termination of the African Humid Period: rapid climate responses to gradual insolation forcing, Quaternary Sci. Rev., 19, 347-361, doi:10.1016/S0277-3791(99)00081-5, 2000.

Desprat, S., Combourieu-Nebout, N., Essallami, L., Sicre, M. A., Dormoy, I., Peyron, O., Siani, G., Bout Roumazeilles, V., and Turon, J. L.: Deglacial and Holocene vegetation and climatic changes in the southern Central Mediterranean from a direct land-sea correlation, Clim. Past, 9, 767-787, doi:10.5194/cp-9767-2013, 2013.

Drine A.: Le site d'El-Mdeina au sud d'El-Biban, la Zouchis de Strabon, Reppal, Centre d'Etudes de la Civilisation Phénicienne - Punique et des Antiquités Libyques, 7-8, 103-115, 1993.

Dünkeloh, A. and Jacobeit, J.: Circulation dynamics of Mediterranean precipitation variability 1948-98, Int. J. Climatol., 23, 1843-1866, doi:10.1002/joc.973, 2003.

Edmunds, W. M., Dodo, A., Djoret, D., Gaye, C., Goni, I., Travi, Y., Zouari, K., Zuppi, G.-M., and Gasse, F.: Groundwater as an archive of climatic and environmental change: Europe to Africa, in: Past Climate Variability through Europe and Africa, edited by: Battarbee, R., Gasse, F., and Stickley, C., Developments in Paleoenvironmental Research, Springer, the Netherlands, 279306, 2004.

El-Rishi, H., Hunt, C., Gilbertson, D. D., Grattan, J., McLaren, S., Pyatt, B., Duller, G., Gillmore, G., and Phillips, P.: The past and present landscapes of the Wadi Faynan: geoarchaeological approaches and frameworks, in: Archaeology and desertification: The Wadi Faynan landscape survey, Southern Jordan, edited by: Barker, G., Gilbertson, D., and Mattingly, D., CBRL Levant Series 6, Oxbow Books, Oxford, 59-95, 2007.

Esper, J., Frank, D., Büntgen, U., Verstege, A., Luterbacher, J., and Xoplaki, E.: Long-term drought severity variations in Morocco, Geophys. Res. Lett., 34, L17702, doi:10.1029/2007GL030844, 2007.

Faust, D., Zielhofer, C., Baena Escudero, R., and Diaz del Olmo, F.: High-resolution fluvial record of late Holocene geomorphic change in northern Tunisia: climatic or human impact?, Quaternary Sci. Rev., 23, 1757-1775, doi:10.1016/j.quascirev.2004.02.007, 2004.

Finné, M., Holmgren, K., Sundqvist, H. S., Weiberg, E., and Lindblom, M.: Climate in the eastern Mediterranean, and adjacent regions, during the past 6000 years - A review, J. Archaeol. Sci., 38, 3153-3173, doi:10.1016/j.jas.2011.05.007, 2011.

Fletcher, W. J. and Zielhofer, C.: Fragility of Western Mediterranean landscapes during Holocene Rapid Climate Changes, CATENA, 103, 16-29, doi:10.1016/j.catena.2011.05.001, 2013.

Fletcher, W. J., Sanchez Goñi, M. F., Peyron, O., and Dormoy, I.: Abrupt climate changes of the last deglaciation detected in a Western Mediterranean forest record, Clim. Past, 6, 245-264, doi:10.5194/cp-6-245-2010, 2010.

Fletcher, W. J., Debret, M., and Sanchez Goñi, M. F.: Mid-Holocene emergence of a low-frequency millennial oscillation in western Mediterranean climate: Implications for past dynamics of the North Atlantic atmospheric westerlies, The Holocene, 23, 153 166, doi:10.1177/0959683612460783, 2012.

Floret, C. and Pontanier, R.: L'aridité en Tunisie présaharienne : climat, sol, végétation et aménagement, Travaux et Documents de l'ORSTOM, 150, ORSTOM, Paris, 552 pp., 1982. 
Formenti, P., Schütz, L., Balkanski, Y., Desboeufs, K., Ebert, M., Kandler, K., Petzold, A., Scheuvens, D., Weinbruch, S., and Zhang, D.: Recent progress in understanding physical and chemical properties of African and Asian mineral dust, Atmos. Chem. Phys., 11, 8231-8256, doi:10.5194/acp-11-8231-2011, 2011.

Foucault, A. and Mélières, F.: Palaeoclimatic cyclicity in central Mediterranean Pliocene sediments: the mineralogical signal, Palaeogeogr. Palaeocl., 158, 311-323, doi:10.1016/S00310182(00)00056-0, 2000.

Frankenberg, P.: Zeitlicher Vegetationswandel und Vegetationsrekonstruktion des "neolithischen Klimaoptimums" in der Jeffara Südosttunesiens, Abhandlungen der MathematischNaturwissenschaftlichen Klasse, 4, Akademie der Wissenschaften und der Literatur, Stuttgart, 83 pp., 1986.

Friendly, M.: Corrgrams, Am. Stat., 56, 316-324, doi:10.1198/000313002533, 2002.

Gamoun, M.: Grazing intensity effects on the vegetation in desert rangelands of Southern Tunisia, J. Arid Land, 6, 324-333, doi:10.1007/s40333-013-0202-y, 2014.

Gammar A.-M.: Carte de la végétation de la Tunisie, in: Atlas de l'eau en Tunisie, edited by: Henia L., Faculté des sciences humaines et sociales de Tunis, 130-133, 2008.

Gao, X. and Giorgi, F.: Increased aridity in the Mediterranean region under greenhouse gas forcing estimated from high resolution simulations with a regional climate model, Global Planet. Change, 62, 195-209, doi:10.1016/j.gloplacha.2008.02.002, 2008.

Gasse, F.: Hydrological changes in the African tropics since the Last Glacial Maximum, Quaternary Sci. Rev., 19, 189-211, doi:10.1016/S0277-3791(99)00061-X, 2000.

Gasse, F.: Diatom-inferred salinity and carbonate oxygen isotopes in Holocene waterbodies of the western Sahara and Sahel (Africa), Quaternary Sci. Rev., 21, 737-767, doi:10.1016/S02773791(01)00125-1, 2002.

Gasse, F. and Roberts, C. N.: Late Quaternary Hydrologic Changes in the Arid and Semiarid Belt of Northern Africa, in: The Hadley Circulation: Present, Past and Future, edited by: Diaz, H. and Bradley, R., Advances in Global Change Research, Springer, the Netherlands, 313-345, 2004.

Genin, D., Guillaume, H., Ouessar, M., Ouled Belgacem, A., Romagny, B., Sghaïer, M., and Taamallah, H.: Entre désertification et développement: la Jeffara tunisienne, IRD-Cérès, Tunis, 351 pp., 2006.

Genty, D., Blamart, D., Ghaleb, B., Plagnes, V., Causse, C., Bakalowicz, M., Zouari, K., Chkir, N., Hellstrom, J., Wainer, K., and Bourges, F.: Timing and dynamics of the last deglaciation from European and North African $\delta^{13} \mathrm{C}$ stalagmite profiles-comparison with Chinese and South Hemisphere stalagmites, Quaternary Sci. Rev., 25, 2118-2142, doi:10.1016/j.quascirev.2006.01.030, 2006.

Giannakopoulos, C., Le Sager, P., Bindi, M., Moriondo, M., Kostopoulou, E., and Goodess, C. M.: Climatic changes and associated impacts in the Mediterranean resulting from a $2{ }^{\circ} \mathrm{C}$ global warming, Global Planet. Change, 68, 209-224, doi:10.1016/j.gloplacha.2009.06.001, 2009.

Gibert, E., Arnold, M., Conrad, G., De Deckker, P., Fontes, J. C., Gasse, F., and Kassir, A.: Retour des conditions humides au Tardiglaciaire au Sahara septentrional (sebkha
Mellala, Algerie), B. Soc. Geol. France, VI, 497-504, doi:10.2113/gssgfbull.VI.3.497, 1990.

Gilbertson, D. D., Hunt, C. O., and Smithson, P. A.: Quaternary geomorphology and palaeoecology, in: Farming the desert: the UNESCO Libyan Valleys Archaeological Survey, Volume one, Synthesis, edited by: Barker, G., UNESCO Publishing, Paris, 4982, 1996.

Giorgi, F. and Lionello, P.: Climate change projections for the Mediterranean region, Global Planet. Change, 63, 90-104, doi:10.1016/j.gloplacha.2007.09.005, 2008.

Giraudi, C., Mercuri, A. M., and Esu, D.: Holocene palaeoclimate in the northern Sahara margin (Jefara Plain, northwestern Libya), The Holocene, 23, 339-352, doi:10.1177/0959683612460787, 2013.

Goudie, A. S. and Middleton, N. J.: Saharan dust storms: nature and consequences, Earth-Sci. Rev., 56, 179-204, doi:10.1016/S00128252(01)00067-8, 2001.

Graham, N. E., Ammann, C. M., Fleitmann, D., Cobb, K. M., and Luterbacher, J.: Support for global climate reorganization during the "Medieval Climate Anomaly", Clim. Dynam., 37, 12171245, doi:10.1007/s00382-010-0914-z, 2011.

Grimm, E. C.: CONISS: a FORTRAN 77 program for stratigraphically constrained cluster analysis by the method of incremental sum of squares, Comput. Geosci., 13, 13-35, doi:10.1016/00983004(87)90022-7, 1987.

Guendouz, A., Moulla, A. S., Edmunds, W. M., Zouari, K., Shand, P., and Mamou, A.: Hydrogeochemical and isotopic evolution of water in the Complexe Terminal aquifer in the Algerian Sahara, Hydrogeol. J., 11, 483-495, doi:10.1007/s10040-003-0263-7, 2003.

Hamann, Y., Ehrmann, W., Schmiedl, G., and Kuhnt, T.: Modern and late Quaternary clay mineral distribution in the area of the SE Mediterranean Sea, Quaternary Res., 71, 453-464, doi:10.1016/j.yqres.2009.01.001, 2009.

Hoelzmann, P., Gasse, F., Dupont, L., Salzmann, U., Staubwasser, M., Leuschner, D., and Sirocko, F.: Palaeoenvironmental changes in the arid and sub arid belt (Sahara-Sahel-Arabian Peninsula) from $150 \mathrm{kyr}$ to present, in: Past Climate Variability through Europe and Africa, edited by: Battarbee, R., Gasse, F., and Stickley, C., Developments in Paleoenvironmental Research, Springer, the Netherlands, 219-256, 2004.

Hooghiemstra, H.: Aspects of Neogene-Quaternary environmental and climatic change in equatorial and Saharan Africa, in: Palaeoecology of Africa, 24, 115-132, 1996.

Horowitz, A.: Palynology of Arid Lands, Elsevier, Amsterdam, 546 pp., 1992.

Hunt, C. O., Elrishi, H. A., and Hassan, A. T.: Reconnaissance investigation of the palynology of Holocene wadi deposits in Cyrenaica, Libya, Libyan Studies, 33, 1-7, doi:10.1017/S0263718900005070, 2002.

Hunt, C. O., Gilbertson, D. D., and El-Rishi, H. A.: An 8000year history of landscape, climate, and copper exploitation in the Middle East: the Wadi Faynan and the Wadi Dana National Reserve in southern Jordan, J. Archaeol. Sci., 34, 1306-1338, doi:10.1016/j.jas.2006.10.022, 2007.

Hunt, C. O., Davison, J., Inglis, R., Farr, L., Reynolds, T., Simpson, D., el-Rishi, H., and Barker, G.: Site formation processes in caves: The Holocene sediments of the Haua 
Fteah, Cyrenaica, Libya, J. Archaeol. Sci., 37, 1600-1611, doi:10.1016/j.jas.2010.01.021, 2010.

Hunt, C. O., Brooks, I., Meneely, J., Brown, D., Buzaian, A., and Barker, G.: The Cyrenaican Prehistory Project 2011: Late-Holocene environments and human activity from a cave fill in Cyrenaica, Libya, Libyan Studies, 42, 77-87, doi:10.1017/S0263718900004830, 2011.

IPCC: Climate Change 2014: Synthesis Report, Contribution of Working Groups I, II and III to the Fifth Assessment Report of the Intergovernmental Panel on Climate Change, edited by: Pachauri, R. K., and Meyer, L. A., IPCC, Geneva, Switzerland, 151 pp., 2014.

Jackes, M. and Lubell, D.: Early and Middle Holocene Environments and Capsian Cultural Change: Evidence from the Télidjène Basin, Eastern Algeria, Afr. Archaeol. Rev., 25, 41-55, doi:10.1007/s10437-008-9024-2, 2008.

Jaouadi, S., Lebreton, V., Mannai-Tayech, B., Lakhdar, R., and Soussi, M.: Apport de l'analyse pollinique des sédiments de la sebkha Boujmel (Sud-Est tunisien) à la reconstitution des paléopysages et paléoclimats holocènes en milieu aride, Méditerranée, 125, in press, 2016.

Juggins, S.: rioja: Analysis of Quaternary Science Data, R package version (0.9-5), The Comprehensive R Archive Network, 2015.

Kaniewski, D., Van Campo, E., Paulissen, E., Weiss, H., Bakker, J., Rossignol, I., and Van Lerberghe, K.: The medieval climate anomaly and the little Ice Age in coastal Syria inferred from pollen-derived palaeoclimatic patterns, Global Planet. Change, 78, 178-187, doi:10.1016/j.gloplacha.2011.06.010, 2011.

Keer, F. R.: The Sedimentary Framework of a Desert Coastal Lagoon, Bahiret El Bibane - Tunisia, Master thesis, Duke University, North Carolina, 93 pp., 1976.

Kotthoff, U., Müller, U. C., Pross, J., Schmiedl, G., Lawson, I. T., van de Schootbrugge, B., and Schulz, H.: Lateglacial and Holocene vegetation dynamics in the Aegean region: an integrated view based on pollen data from marine and terrestrial archives, The Holocene, 18, 1019-1032, doi:10.1177/0959683608095573, 2008a.

Kotthoff, U., Pross, J., Müller, U. C., Peyron, O., Schmiedl, G., Schulz, H., and Bordon, A.: Climate dynamics in the borderlands of the Aegean Sea during formation of sapropel S1 deduced from a marine pollen record, Quaternary Sci. Rev., 27, 832-845, doi:10.1016/j.quascirev.2007.12.001, 2008b.

Kröpelin, S., Verschuren, D., Lézine, A.-M., Eggermont, H., Cocquyt, C., Francus, P., Cazet, J.-P., Fagot, M., Rumes, B., Russell, J. M., Darius, F., Conley, D. J., Schuster, M., von Suchodoletz, H., and Engstrom, D. R.: Climate-Driven Ecosystem Succession in the Sahara: The Past 6000 Years, Science, 320, 765-768, doi:10.1126/science.1154913, 2008.

Kutzbach, J. E. and Liu, Z.: Response of the African Monsoon to Orbital Forcing and Ocean Feedbacks in the Middle Holocene, Science, 278, 440-443, doi:10.1126/science.278.5337.440, 1997.

Kutzbach, J. E., Chen, G., Cheng, H., Edwards, R. L., and Liu, Z.: Potential role of winter rainfall in explaining increased moisture in the Mediterranean and Middle East during periods of maximum orbitally-forced insolation seasonality, Clim. Dynam., 42, 1079-1095, doi:10.1007/s00382-013-1692-1, 2014.

Lakhdar, R., Soussi, M., Ben Ismail, M. H., and M'Rabet, A.: A Mediterranean Holocene restricted coastal lagoon un- der arid climate: Case of the sedimentary record of Sabkha Boujmel (SE Tunisia), Palaeogeogr. Palaeocl., 241, 177-191, doi:10.1016/j.palaeo.2006.02.014, 2006.

Lakhdar, R.: Les sédiments holocènes et les tapis microbiens du littoral du Sud-Est de la Tunisie: sédimentologie et paléoenvironnements, PhD, Université de Sfax, 207 pp., 2009.

Le Floc'h, E., Boulos, L., and Vela, E.: Catalogue synonymique commenté de la Flore de Tunisie, Ministère de l'Environnement et du Développement durable - Banque Nationale de Gènes, Montpellier-Tunis, 500 pp., 2010.

Le Houérou, H. N.: Recherches écologiques et floristiques sur la végétation de la Tunisie méridionale, Institut de Recherches Sahariennes, Université d'Alger, 508 pp., 1959.

Le Houérou, H. N.: La Végétation de la Tunisie steppique (avec références aux végétations analogues d'Algérie, de Libye et du Maroc), Annales de l'Institut National de la Recherche Agronomique de Tunisie, 42, 624 pp., 1969.

Le Houérou, H. N.: Browse in northern Africa, in: Browse in Africa: The Current State of Knowledge, edited by: Le Houérou, H. N., International Livestock Centre for Africa, Addis Ababa, 83-102, 1980.

Le Houérou, H. N.: Bioclimatologie et biogéographie des steppes arides du Nord de l'Afrique, Options méditerranéennes, Série B; Etudes \& recherches, Montpellier, CIHEAM, 396 pp., 1995.

Lebreton, V. and Jaouadi, S.: Histoire holocène de la végétation sur le littoral de la Tunisie centrale: analyse pollinique des sédiments de la sebkha-lagune Halk el Manjel, in: Le Capsien de Hergla (Tunisie): Culture, environnement et économie, edited by: Mulazzani, S., Reports in African Archaeology, 4, Africa Magna Verlag, Frankfurt am Main, 48-56, 2013.

Lebreton, V., Jaouadi, S., Mulazzani, S., Boujelben, A., Belhouchet, L., Gammar, A. M., Combourieu-Nebout, N., Saliège, J.-F., Karray, M. R., and Fouache, E.: Early oleiculture or native wild Olea in eastern Maghreb: new pollen data from the sebkha-lagoon Halk el Menjel (Hergla, Central Tunisia), Environmental Archaeology, 20, 265-273, doi:10.1179/1749631414Y.0000000046, 2015.

Lézine, A.-M., Zheng, W., Braconnot, P., and Krinner, G.: Late Holocene plant and climate evolution at Lake Yoa, northern Chad: pollen data and climate simulations, Clim. Past, 7, 13511362, doi:10.5194/cp-7-1351-2011, 2011.

Lionello, P., Malanotte-Rizzoli, P., Boscolo, R., Alpert, P., Artale, V., Li, L., Luterbacher, J., May, W., Trigo, R., Tsimplis, M., Ulbrich, U., and Xoplaki, E.: The Mediterranean climate: An overview of the main characteristics and issues, in: Mediterranean Climate Variability, edited by: Lionello, P., MalanotteRizzoli, P., and Boscolo, R., Developments in Earth and Environmental Sciences, 4, Elsevier, 1-26, 2006.

Lubell, D., Hassan, F. A., Gautier, A., and Ballais, J.L.: The Capsian Escargotières, Science, 191, 910-920, doi:10.1126/science.191.4230.910, 1976.

Lucarini, G.: Was a transition to food production homogeneous along the circum-Mediterranean littoral? A perspective on the Neolithisation research from the Libyan littoral, in: Neolithisation of Northeastern Africa, edited by: Shirai, N., Studies in Early Near Eastern Production, Subsistence, and Environment, 16, ex oriente, Berlin, 149-174, 2013.

Magny, M., Vannière, B., Zanchetta, G., Fouache, E., Touchais, G., Petrika, L., Coussot, C., Walter-Simonnet, A.-V., and Arnaud, F.: 
Possible complexity of the climatic event around 4300-3800 cal. BP in the central and western Mediterranean, The Holocene, 19, 823-833, doi:10.1177/0959683609337360, 2009.

Magny, M., Vannière, B., Calo, C., Millet, L., Leroux, A., Peyron, O., Zanchetta, G., La Mantia, T., and Tinner, W.: Holocene hydrological changes in south-western Mediterranean as recorded by lake-level fluctuations at Lago Preola, a coastal lake in southern Sicily, Italy, Quaternary Sci. Rev., 30, 2459-2475, doi:10.1016/j.quascirev.2011.05.018, 2011.

Magny, M., Peyron, O., Sadori, L., Ortu, E., Zanchetta, G., Vannière, B., and Tinner, W.: Contrasting patterns of precipitation seasonality during the Holocene in the south- and north-central Mediterranean, J. Quaternary Sci., 27, 290-296, doi:10.1002/jqs.1543, 2012.

Magny, M., Combourieu-Nebout, N., de Beaulieu, J. L., BoutRoumazeilles, V., Colombaroli, D., Desprat, S., Francke, A., Joannin, S., Ortu, E., Peyron, O., Revel, M., Sadori, L., Siani, G., Sicre, M. A., Samartin, S., Simonneau, A., Tinner, W., Vannière, B., Wagner, B., Zanchetta, G., Anselmetti, F., Brugiapaglia, E., Chapron, E., Debret, M., Desmet, M., Didier, J., Essallami, L., Galop, D., Gilli, A., Haas, J. N., Kallel, N., Millet, L., Stock, A., Turon, J. L., and Wirth, S.: North-south palaeohydrological contrasts in the central Mediterranean during the Holocene: tentative synthesis and working hypotheses, Clim. Past, 9, 20432071, doi:10.5194/cp-9-2043-2013, 2013.

Mann, M. E., Zhang, Z., Rutherford, S., Bradley, R. S., Hughes, M. K., Shindell, D., Ammann, C., Faluvegi, G., and Ni, F.: Global Signatures and Dynamical Origins of the Little Ice Age and Medieval Climate Anomaly, Science, 326, 1256-1260, 2009.

Marquer, L., Pomel, S., Abichou, A., Schulz, E., Kaniewski, D., and Van Campo, E.: Late Holocene high resolution palaeoclimatic reconstruction inferred from Sebkha Mhabeul, southeast Tunisia, Quaternary Res., 70, 240-250, doi:10.1016/j.yqres.2008.06.002, 2008.

Martín-Puertas, C., Valero-Garcés, B. L., Pilar Mata, M., GonzálezSampériz, P., Bao, R., Moreno, A., and Stefanova, V.: Arid and humid phases in southern Spain during the last 4000 years: the Zoñar Lake record, Córdoba, The Holocene, 18, 907-921, doi:10.1177/0959683608093533, 2008.

Mattingly, D. J.: Tripolitania, Batsford, London, 465 pp., 1995.

Mattingly, D. J., Reynolds, T., and Dore, J.: Synthesis of human activities in Fazzan, in: The archaeology of Fazzan Volume 1, Synthesis, edited by: Mattingly, D. J., Department of Antiquities, Tripoli and Society for Libyan Studies, London, 327-373, 2003.

Mayewski, P. A., Rohling, E. E., Curt Stager, J., Karlén, W., Maasch, K. A., David Meeker, L., Meyerson, E. A., Gasse, F., van Kreveld, S., Holmgren, K., Lee-Thorp, J., Rosqvist, G., Rack, F., Staubwasser, M., Schneider, R. R., and Steig, E. J.: Holocene climate variability, Quaternary Res., 62, 243-255, doi:10.1016/j.yqres.2004.07.001, 2004.

McGee, D., deMenocal, P. B., Winckler, G., Stuut, J. B. W., and Bradtmiller, L. I.: The magnitude, timing and abruptness of changes in North African dust deposition over the last 20,000 yr, Earth Planet. Sc. Lett., 371-372, 163-176, doi:10.1016/j.eps1.2013.03.054, 2013.

Medhioub, K. and Perthuisot, J.-P.: The influence of peripheral sabkhas on the geochemistry and sedimentology of a Tunisian lagoon: Bahiret el Biban, Sedimentology, 28, 679-688, doi:10.1111/j.1365-3091.1981.tb01928.x, 1981.
Mercuri, A. M.: Human influence, plant landscape evolution and climate inferences from the archaeobotanical records of the Wadi Teshuinat area (Libyan Sahara), J. Arid Environ., 72, 1950-1967, doi:10.1016/j.jaridenv.2008.04.008, 2008.

Morton, R. A. and White, W. A.: Characteristics of and Corrections for Core Shortening in Unconsolidated Sediments, J. Coastal Res., 13, 761-769, 1997.

Mrabet, A.: Identité de la Tripolitaine occidentale: de quelques signalements archéologiques, in: Provinces et identités provinciales dans l'Afrique romaine, edited by: Briand-Ponsart, B. and Modéran, Y., Tables rondes du CRAHME, 6, Caen, 221-237, 2011.

Mulazzani, S.: Le Capsien de Hergla (Tunisie): Culture, Environnement Et économie, Reports in African Archaeology, 4, Africa Magna Verlag, Frankfurt am Main, 436 pp., 2013.

Nasr, Z., Almohammed, H., Gafrej Lahache, R., Maag, C., and King, L.: Drought modelling under climate change in Tunisia during the 2020 and 2050 periods, in: Drought management: scientific and technological innovations, edited by: López-Francos, A., Options Méditerranéennes : Série A. Séminaires Méditerranéens, Zaragoza: CIHEAM, 365-370, 2008.

Nasri, S., Albergel, J., Cudennec, C., and Berndtsson, R.: Hydrological processes in macrocatchment water harvesting in the arid region of Tunisia: the traditional system of tabias/Processus hydrologiques au sein d'un aménagement de collecte des eaux dans la région aride tunisienne: le système traditionnel des tabias, Hydrolog. Sci. J., 49, 261-272, doi:10.1623/hysj.49.2.261.34838, 2004.

Neumann, F. H., Kagan, E. J., Leroy, S. A. G., and Baruch, U.: Vegetation history and climate fluctuations on a transect along the Dead Sea west shore and their impact on past societies over the last 3500 years, J. Arid Environ., 74, 756-764, doi:10.1016/j.jaridenv.2009.04.015, 2010.

Nieto-Moreno, V., Martinez-Ruiz, F., Giralt, S., Gallego-Torres, D., García-Orellana, J., Masqué, P., and Ortega-Huertas, M.: Climate imprints during the "Medieval Climate Anomaly" and the "Little Ice Age" in marine records from the Alboran Sea basin, The Holocene, 23, 1227-1237, doi:10.1177/0959683613484613, 2013.

Nowicke, J. W.: Pollen morphology in the order Centrospermae, Grana Palynol., 15, 51-77, 1975.

Nowicke, J. W. and Skvarla, J. J.: Pollen morphology: the potential influence in higher order systematics, Ann. Mo. Bot. Gard., 66, 633-700, 1979.

O’Hara, S. L., Clarke, M. L., and Elatrash, M. S.: Field measurements of desert dust deposition in Libya, Atmos. Environ., 40, 3881-3897, doi:10.1016/j.atmosenv.2006.02.020, 2006.

Ozenda, P.: Flore et végétation du Sahara, 3 Edn., CNRS éditions, Paris, 2004.

Pelling, R.: Garamantian agriculture and its significance in a wider North African context: The evidence of the plant remains from the Fazzan project, The Journal of North African Studies, 10, 397-412, doi:10.1080/13629380500336763, 2005.

Perthuisot, J. P.: La Sebkha el Melah de Zarzis: genèse et évolution d'un bassin salin paralique, Travaux du Laboratoire de Géologie, 9, École Normale Supérieure, Paris, 252 pp., 1975.

Petschick, R.: MacDiff v 4.2.5 (Free Geological Software), Geologisch-Palaontologisches Institut, Universitat Frankfurt/Main, available at: http://www.geol-pal.unifrankfurt.de/ 
Staff/Homepages/Petschick/classicsoftware.html (last access: 2 July 2012), 2001.

Peyron, O., Goring, S., Dormoy, I., Kotthoff, U., Pross, J., de Beaulieu, J.-L., Drescher-Schneider, R., Vannière, B., and Magny, M.: Holocene seasonality changes in the central Mediterranean region reconstructed from the pollen sequences of Lake Accesa (Italy) and Tenaghi Philippon (Greece), The Holocene, 21, 131-146, doi:10.1177/0959683610384162, 2011.

Peyron, O., Magny, M., Goring, S., Joannin, S., de Beaulieu, J.L., Brugiapaglia, E., Sadori, L., Garfi, G., Kouli, K., Ioakim, C., and Combourieu-Nebout, N.: Contrasting patterns of climatic changes during the Holocene across the Italian Peninsula reconstructed from pollen data, Clim. Past, 9, 1233-1252, doi:10.5194/cp-9-1233-2013, 2013.

Pons, A. and Quézel, P.: À propos de la mise en place du climat méditerranéen, C. R. Acad. Sci. IIA, 327, 755-760, doi:10.1016/S1251-8050(99)80047-0, 1998.

Pottier-Alapetite, G.: Flore de la Tunisie: AngiospermesDicotyledones-Apetales-Dialypetales, Tunis, 1979.

Pottier-Alapetite, G.: Flore de la Tunisie: AngiospermesDicotyledones-Gamopetales, Tunis, 1981.

R Core Team: A language and environment for statistical computing. R Foundation for Statistical Computing, Vienna, Austria, ISBN 3-900051-07-0, 2013.

Reille, M.: Pollen et spores d'Europe et d'Afrique du nord, Laboratoire de Botanique Historique et Palynologie, Marseille, 1992.

Reimer, P. J., Bard, E., Bayliss, A., Beck, J. W., Blackwell, P. G., Bronk Ramsey, C., Buck, C. E., Cheng, H., Edwards, R. L., Friedrich, M., Grootes, P. M., Guilderson, T. P., Haflidason, H., Hajdas, I., Hatté, C., Heaton, T. J., Hoffmann, D. L., Hogg, A. G., Hughen, K. A., Kaiser, K. F., Kromer, B., Manning, S. W., Niu, M., Reimer, R. W., Richards, D. A., Scott, E. M., Southon, J. R., Staff, R. A., Turney, C. S. M., and van der Plicht, J.: IntCal13 and Marine13 Radiocarbon Age Calibration Curves 0-50,000 Years cal BP, Radiocarbon, 55, 1869-1887, doi:10.2458/azu_js_rc.55.16947, 2013.

Ritchie, J. C. and Haynes, C. V.: Holocene vegetation zonation in the eastern Sahara, Nature, 330, 645-647, 1987.

Ritchie, J. C., Eyles, C. H., and Haynes, C. V.: Sediment and pollen evidence for an early to mid-Holocene humid period in the eastern Sahara, Nature, 314, 352-355, 1985.

Roberts, N., Brayshaw, D., Kuzucuoğlu, C., Perez, R., and Sadori, L.: The mid-Holocene climatic transition in the Mediterranean: Causes and consequences, The Holocene, 21, 3-13, doi:10.1177/0959683610388058, 2011.

Roubet, C.: "Statut de Berger " des communautés atlasiques, néolithisées du Maghreb oriental, dès 7000 BP, L'Anthropologie, 107, 393-442, doi:10.1016/S0003-5521(03)00024-4, 2003.

Ruan, J., Kherbouche, F., Genty, D., Blamart, D., Cheng, H., Dewilde, F., Hachi, S., Edwards, R. L., Régnier, E., and Michelot, J.-L.: Evidence of a prolonged drought ca. $4200 \mathrm{yr}$ BP correlated with prehistoric settlement abandonment from the Gueldaman GLD1 Cave, Northern Algeria, Clim. Past, 12, 1-14, doi:10.5194/cp-12-1-2016, 2016.

Sadori, L., Jahns, S., and Peyron, O.: Mid-Holocene vegetation history of the central Mediterranean, The Holocene, 21, 117-129, doi:10.1177/0959683610377530, 2011.

Sadori, L., Giraudi, C., Masi, A., Magny, M., Ortu, E., Zanchetta, G., and Izdebski, A.: Climate, environment and society in south- ern Italy during the last 2000 years. A review of the environmental, historical and archaeological evidence, Quaternary Sci. Rev., 136, 173-188, doi:10.1016/j.quascirev.2015.09.020, 2016.

Salzmann, U. and Schulz, E.: Modern pollen rain and Late Holocene vegetation history of southern Tunisia, Publication occasionnelle du CIFEG, 31, 183-192, 1995.

Schaaf, T.: UNESCO's Experience of Fifty Years of Drylands Research and Outreach, in: The Future of Drylands, edited by: Lee, C. and Schaaf, T., Springer, the Netherlands, 775-786, 2008.

Schmiedl, G., Kuhnt, T., Ehrmann, W., Emeis, K.-C., Hamann, Y., Kotthoff, U., Dulski, P., and Pross, J.: Climatic forcing of eastern Mediterranean deep-water formation and benthic ecosystems during the past 22000 years, Quaternary Sci. Rev., 29, 30063020, doi:10.1016/j.quascirev.2010.07.002, 2010.

Schulz, E.: The recent pollen rain in the eastern central Sahara. A transect between northern Libya and southern Niger, Palaeoeco. A., 16, 245-253, 1984.

Schulz, E., Abichou, A., Hachicha, T., Pomel, S., Salzmann, U., and Zouari, K.: Sebkhas as ecological archives and the vegetation and landscape history of southeastern Tunisia during the last two millennia, J. Afr. Earth Sci., 34, 223-229, doi:10.1016/S08995362(02)00021-0, 2002.

Schulz, E., Abichou, A., Adamou, A., Ballouche, A., and Ousseïni, I.: The desert in the Sahara. Transitions and boundaries, in: Holocene Palaeoenvironmental History of the Central Sahara, edited by: Baumhauer, R., and Runge, J., Palaeoecology of Africa, 29, CRC Press, 64-89, 2009.

Sghaier, M., Arbi, A.-M., Tonneau, J.-P., Ounalli, N., Jeder, H., and Bonin, M.: Land Degradation in the Arid Jeffara Region, Tunisia in: Land Use Policies for Sustainable Development: Exploring Integrated Assessment Approaches, edited by: McNeill, D., Nesheim, I., and Brouwer, F., Edward Elgar, 89-109, 2012.

Shipley, G.: Pseudo-Skylax's Periplous: The Circumnavigation of the Inhabited World: Text, Translation and Commentary, Bristol Phoenix Press, 2011.

Siani, G., Paterne, M., Michel, E., Sulpizio, R., Sbrana, A., Arnold, M., and Haddad, G.: Mediterranean Sea Surface Radiocarbon Reservoir Age Changes Since the Last Glacial Maximum, Science, 294, 1917-1920, doi:10.1126/science.1063649, 2001.

Smykatz-Kloss, W. and Felix-Henningsen, P.: The Importance of Desert Margins as Indicators for Global Climatic Fluctuations (Introduction), in: Paleoecology of Quaternary Drylands, edited by: Smykatz-Kloss, W. and Felix-Henningsen, P., Lecture Notes in Earth Sciences, Springer, Berlin Heidelberg, 1-3, 2004.

Stockmarr, J.: Tablets with spores used in absolute pollen analysis, Pollen et Spore, 13, 615-621, 1971.

Swezey, C., Lancaster, N., Kocurek, G., Deynoux, M., Blum, M., Price, D., and Pion, J.-C.: Response of aeolian systems to Holocene climatic and hydrologic changes on the northern margin of the Sahara: a high-resolution record from the Chott Rharsa basin, Tunisia, The Holocene, 9, 141-147, doi:10.1191/095968399670329816, 1999.

Swezey, C.: Eolian sediment responses to late Quaternary climate changes: temporal and spatial patterns in the Sahara, Palaeogeogr. Palaeocl., 167, 119-155, doi:10.1016/S00310182(00)00235-2, 2001.

Swingedouw, D., Terray, L., Cassou, C., Voldoire, A., Salas-Mélia, D., and Servonnat, J.: Natural forcing of climate during the last 
millennium: fingerprint of solar variability, Clim. Dynam., 36, 1349-1364, doi:10.1007/s00382-010-0803-5, 2011.

Talbi, M.: Action anthropique et dégradation de l'environnement aride: la désertification en Tunisie du Sud-Est, Méditerranée, 86, 25-31, 1997.

Talbi, M., Ben-Mansour, N., Talbi, K., and Gasmi, N.: Changes in the resources management and their environmental consequences in a Saharan arid environment, in: Desertification and Risk Analysis Using High and Medium Resolution Satellite Data, edited by: Marini, A. and Talbi, M., NATO Science for Peace and Security Series C: Environmental Security, Springer, the Netherlands, 27-46, 2009.

Tarhouni, M., Ben Salem, F., Ouled Belgacem, A., and Neffati, M.: Acceptability of plant species along grazing gradients around watering points in Tunisian arid zone, Flora - Morphology, Distribution, Functional Ecology of Plants, 205, 454-461, doi:10.1016/j.flora.2009.12.020, 2010.

Tierney, J. E. and deMenocal, P. B.: Abrupt Shifts in Horn of Africa Hydroclimate Since the Last Glacial Maximum, Science, 342, 843-846, doi:10.1126/science.1240411, 2013.

Traverse, A.: Paleopalynology, Springer Topics in Geobiology, 28, Springer, 814 pp., 2007.

Trigo, R. M., Pozo-Vázquez, D., Osborn, T. J., Castro-Díez, Y., Gámiz-Fortis, S., and Esteban-Parra, M. J.: North Atlantic oscillation influence on precipitation, river flow and water resources in the Iberian Peninsula, Int. J. Climatol., 24, 925-944, doi:10.1002/joc.1048, 2004.

Trouet, V., Esper, J., Graham, N. E., Baker, A., Scourse, J. D., and Frank, D. C.: Persistent Positive North Atlantic Oscillation Mode Dominated the Medieval Climate Anomaly, Science, 324, 78-80, 2009.

Trousset, P. and Paskoff, R.: Biban (Les Portes), Encyclopédie berbère, 10, 1488-1492, 1991.
Tzedakis, P. C.: Seven ambiguities in the Mediterranean palaeoenvironmental narrative, Quaternary Sci. Rev., 26, 2042-2066, doi:10.1016/j.quascirev.2007.03.014, 2007.

van der Veen, M.: Garamantian Agriculture: The Plant Remains from Zinchecra, Fezzan, Libyan Studies, 23, 7-39, doi:10.1017/S0263718900001722, 1992.

Walker, M. J. C., Berkelhammer, M., Björck, S., Cwynar, L. C., Fisher, D. A., Long, A. J., Lowe, J. J., Newnham, R. M., Rasmussen, S. O., and Weiss, H.: Formal subdivision of the Holocene Series/Epoch: a Discussion Paper by a Working Group of INTIMATE (Integration of ice-core, marine and terrestrial records) and the Subcommission on Quaternary Stratigraphy (International Commission on Stratigraphy), J. Quaternary Sci., 27, 649-659, doi:10.1002/jqs.2565, 2012.

Wanner, H., Solomina, O., Grosjean, M., Ritz, S. P., and Jetel, M.: Structure and origin of Holocene cold events, Quaternary Sci. Rev., 30, 3109-3123, doi:10.1016/j.quascirev.2011.07.010, 2011.

Wassenburg, J. A., Immenhauser, A., Richter, D. K., Niedermayr, A., Riechelmann, S., Fietzke, J., Scholz, D., Jochum, K. P., Fohlmeister, J., Schröder-Ritzrau, A., Sabaoui, A., Riechelmann, D. F. C., Schneider, L., and Esper, J.: Moroccan speleothem and tree ring records suggest a variable positive state of the North Atlantic Oscillation during the Medieval Warm Period, Earth Planet. Sc. Lett., 375, 291-302, doi:10.1016/j.epsl.2013.05.048, 2013.

Zielhofer, C., Faust, D., Escudero, R. B., del Olmo, F. D., Kadereit, A., Moldenhauer, K.-M., and Porras, A.: Centennial-scale latePleistocene to mid-Holocene synthetic profile of the Medjerda Valley, northern Tunisia, The Holocene, 14, 851-861, doi:10.1191/0959683604hl765rp, 2004.

Zoughlami, J.: Le néolithique dans la dorsale tunisienne - Kef El Guéria et sa région, Centre de Publication Universitaire, Tunis, 216 pp., 2009. 